\title{
A Competency Model for the Selection and Performance Improvement of Project Managers in Collaborative Construction Projects: Behavioral Studies in Norway and Finland
}

\author{
Sina Moradi ${ }^{1, *(\mathbb{D})}$, Kalle Kähkönen ${ }^{1}$, Ole Jonny Klakegg ${ }^{2} \mathbb{D}$ and Kirsi Aaltonen ${ }^{3}$ \\ 1 Faculty of Built Environment, Tampere University, Rakennustalo, Korkeakoulunkatu 5, \\ 33720 Tampere, Finland; kalle.kahkonen@tuni.fi \\ 2 Department of Civil and Environmental Engineering, Norwegian University of Science and Technology, \\ Høgskoleringen 1, 7491 Trondheim, Norway; ole.jonny.klakegg@ntnu.no \\ 3 Faculty of Industrial Engineering and Management, University of Oulu, 90014 Oulu, Finland; \\ kirsi.aaltonen@oulu.fi \\ * Correspondence: sina.moradi@tuni.fi
}

Citation: Moradi, S.; Kähkönen, K.; Klakegg, O.J.; Aaltonen, K. A Competency Model for the Selection and Performance Improvement of Project Managers in Collaborative Construction Projects: Behavioral Studies in Norway and Finland. Buildings 2021, 11, 4. https://dx.doi.org/10.3390/ buildings11010004

Received: 22 October 2020

Accepted: 21 December 2020

Published: 23 December 2020

Publisher's Note: MDPI stays neutral with regard to jurisdictional claims in published maps and institutional affiliations.

Copyright: () 2020 by the authors. Licensee MDPI, Basel, Switzerland. This article is an open access article distributed under the terms and conditions of the Creative Commons Attribution (CC BY) license (https: / / creativecommons.org/ licenses/by/4.0/).

\begin{abstract}
Collaborative work practices are getting more common in construction projects. Consequently, new project delivery models have emerged and new practices have also entered the world of traditional delivery models. The resultant collaborative construction projects provide a different working environment compared to the traditional construction delivery models. This different environment seems to require project managers with certain types of competencies, but there is currently very limited research-based knowledge concerning this subject. This study aims at identifying such competencies, which project managers of collaborative construction projects need to possess to succeed. For this purpose, a human behavioral approach was employed where project managers' behavior in their everyday work was the main source for understanding their competencies. Accordingly, the survey strategy was utilized, where a self-evaluation questionnaire was sent to 33 project managers of collaborative construction projects, and a response rate of $73 \%$ was achieved. The findings present four groups of competencies within a matrix model, structured based on their contribution to project managers' successful performance in collaborative construction projects and the degree to which they can develop those competencies. The developed model can provide a baseline for selecting project managers and for enhancing the performance of the current ones.
\end{abstract}

Keywords: competency model; project manager; collaborative construction project; project delivery model

\section{Introduction}

Delivery models of construction projects are subjects of continuous development and changes. Some of them reflect past practices and traditions, but it is possible to recognize developments that can present valuable drivers for improving the performance of construction projects. An example of such developments is shifting from traditional delivery models of construction projects (e.g., design-bid-build, design-build) toward relational contracting/lean project deliveries (also called collaborative project delivery models) [1,2].

In a holistic view, collaborative delivery models of construction projects comprise alliancing, partnering, integrated project delivery (IPD), relational contracting and relationship-based procurement [3,4]. These collaborative delivery models of construction projects are usually characterized by fixed profit, guaranteed variable cost without a cap, profit based on project outcome and limited change orders [5,6]. Moreover, these collaborative delivery models have some key elements such as early involvement of the 
key participants of the project, shared risk-reward based on project outcome, joint project control, and trust-based relationships for collaboration and cooperation [5-7]. The mentioned characteristics and elements direct collaboration and cooperation of the key parties, integrated within a single team, toward the good of the project.

The emergence of collaborative delivery models (with the explained characteristics and elements) for construction projects has led to the creation of a new working environment, compared to the traditional delivery models. This different working environment fosters trust-based collaboration and cooperation toward value maximization and waste reduction for the efficiency of the project, as a whole $[5,6]$. Consequently, amongst the implications of this different working environment are the striking changes in the performance results of the construction projects. For instance, Forbes and Ahmed [1] stated that collaborative delivery models have decreased office construction costs by $25 \%$ within 18 months and schematic design time from 11 to 2 weeks. Moreover, a recent study [8] compared the performance of 109 projects in USA, Canada, Colombia and Ireland in terms of project delivery models. The comparison was carried out based on 11 performance metrics (e.g., construction cost growth, schedule growth, deficiency issues, rework). The findings of this study showed that the construction projects undertaken with collaborative delivery models (in this case IPD) outperformed those ones carried out with traditional delivery models (design-bid-build, construction management and design-build).

Additionally, it is acknowledged that some collaborative working practices are gradually finding their ways also into the traditional delivery models of construction projects. For instance, one of the authors of this study, involved in project management consultancy services, has observed that currently there are a few ongoing partnering construction projects in Norway wherein traditional EPC (Engineering-Procurement-Construction) or design-build contracts are combined with collaborative and/or integrated teams. Construction projects applying collaborative delivery models are also called collaborative construction projects [2,9]. In this study, "traditional construction projects" and "collaborative construction projects", as the clear, concise and meaningful replacements represent the terms "construction projects with traditional delivery models", and "construction projects with collaborative delivery models/working practices", respectively.

The emergent collaborative delivery models (e.g., alliance, IPD) and collaborative ways of working seem also to have effects on the competencies needed for the project managers of collaborative construction projects. In any kind of construction project, a competent project manager significantly contributes to the successful delivery of the project [10-13]. Such competencies are seen as the main predictors and causes of project mangers' successful performance, which in turn has a considerable effect on project success [14-16]. Project managers' competencies can directly account for $35-44 \%$ of project success [17]. Another study has shown that lack of project managers' relevant competencies can account for $60 \%$ of project failures [18]. Thus, different scholars have studied project managers' competencies, mainly in traditional construction projects [19-23]. However, the required competencies for project managers of collaborative construction projects seem to be different due to the focus on no-blame-related behavior, supporting others and collaborative leadership (i.e., bringing up some of the behavioral principles in these projects based on which we can assume that the competency requirements may be different). Therefore, this study aims to contribute toward this subject, limitedly addressed by the research community, by answering the following research question:

$R Q$. What are the appropriate and important competencies of project managers in collaborative construction projects?

The resultant paper is structured as follows. The review of the previous research in the following section is followed by the explanation of the methodology. Then, the findings are presented and discussed. Finally, the conclusions are presented based on the obtained results. 


\section{Theoretical Background}

\subsection{Definition of Competency}

Competencies were explained by Abraham et al. [24] as traits, behaviors, and characteristics which cause successful performance. McClelland [25,26] and Boyatzis [27,28] stated that competency is a capability comprised of related but different sets of behavior emanating from and demonstrating an underlying construct called the intent, which is context-oriented [29].

Spencer and Spencer [15] stated that "a competency is an underlying characteristic of an individual that is causally related to criterion-referenced effective and/or successful performance in a job or situation". Accordingly, underlying characteristics, here, include motives (the things that a person consistently thinks about or wants that cause action), traits (physical characteristics and consistent responses to situations or information), self-concept (a person's attitudes, values or self-image), knowledge (the information a person has in a specific content area) and skills (the ability to perform a certain physical or mental task). According to the Iceberg Model [15], knowledge and skill competencies tend to be visible, and relatively surface, and subsequently easy to develop through training which is the most cost-effective way to secure these employee abilities. Conversely, self-concept, trait and motive competencies are more hidden and central to personality, and consequently are more difficult to assess and develop; it is the most cost-effective way to use those as project managers' recruitment criteria.

Zwell [30] defined competencies as enduring traits or characteristics that are behind certain job performances. The mentioned source also presented a categorization of competencies based on their difficulty of improvement, which seems to be line with the theory of the Iceberg Model. This categorization included three clusters: easy to improve, somewhat hard to improve, and hard to improve competencies. Moradi et al. [31] defined project managers' competencies as "the capabilities of utilizing skills, knowledge and personal characteristics, which improve project managers' effectiveness and efficiency in their job performance and subsequently increase the likelihood of project success". The capabilities present both hidden and visible competencies, building on the principles presented by Spencer and Spencer [15]. The exemplified definitions, in a nutshell, imply that competencies have two important aspects: (i) contribution to successful performance, and (ii) difficulty of improvement.

This study, based on the previous research (particularly [15,25-28,30,31]), defines competencies as underlying characteristics (motives, traits, self-image, skills and knowledge) which cause different kinds of actions while being combined with an intent, which is situation-oriented. The resultant action in a given situation is called competency. Competency, due to its behavioral nature, can predict and cause successful performance in a consistent manner. The mentioned underlying characteristics can be categorized in three groups of highly personality-oriented (motives and traits), knowledge and skill-oriented, and somewhat personality-oriented (self-image). This means that some of the competencies (those related to motive and traits) are central to the personality (e.g., trustworthiness, initiative, optimism). This is the reason for which the previous studies (for instance, $[15,30]$ ) have stated that competencies related to motives and/or traits are hard to develop. In contrary, knowledge and skill-oriented competencies (e.g., management, leadership) are easy to assess and improve because they are detached from the personality and therefore individuals can be easily trained for the knowledge and skills which they lack. Finally, the third group of competencies, called self-image (e.g., self-confidence and self-control), is related to individuals' understanding about their strengths and weaknesses, which lies between the above-mentioned categories.

\subsection{Evolution of Research on Construction Project Managers' Competencies}

According to a recent study [31], the pioneers of research efforts regarding the subject of competency can be attributed to Gaddis [32] for his paper entitled "The Project Manager", Lawrence and Lorsch [33] for their Harvard business review article titled "The Integrator", 
and McClelland [25] for his paper entitled "Testing for Competence Rather Than for Intelligence". These research efforts on the competency subject have been actively followed by different scholars. For instance, the study undertaken by Powers [34] resulted in discovering a set of managerial competencies, characterizing successful performance. These competencies were then grouped within four clusters, including human resource management, goal and action management, directing subordinates and leadership [34]. It can be argued that the ideas of these competency research pioneers, particularly those behavioristics ones (e.g., McClelland, [25]), were followed with a study carried out by Spencer and Spencer [15] which stressed the importance of the behavioral approach for studying the competency and which presented the Iceberg Model. The book entitled Creating a Culture of Competency by Zwell [30] is also another prominent work concerning the competency subject, whereby its categorization of competencies, in terms of improvability, seems to be in line with the theory of the Iceberg Model.

Since 2000, several scholars have actively studied project managers' competencies from general and context-specific perspectives. Two studies carried out by Crawford [35] and Edum-Fotwe and McCaffer [36] aimed to explore the significance of project managers' competencies in construction projects and the correlation of those competencies with project success. These efforts were followed by a study undertaken by Shenhar [37], entitled "one size does not fit all projects: exploring classical contingency domains". He stated that a specific project type affects the selection of project managers, project team members and skill development needs. In other words, Shenhar's finding in terms of the importance of contingency thinking can be seen as the departure point for the succeeding context-specific studies concerning the competency subject. As a result, several studies were undertaken in the following years to identify project managers' competencies in different contexts, such as construction, IT, organizational change, and metallurgical projects (for instance, Refs. [21,38-41]).

Competency studies addressing construction project managers were continued by different researchers (for instance, Refs. [24,42-44]). Consequently, different competencies, such as flexibility, conceptual thinking and knowledge management, were found to be of importance for the project managers in the results of the mentioned research efforts. These efforts were then followed by other scholars and new competencies of importance were discovered, such as adaptability and analytical thinking [45-49].

Regional and cultural differences have also provided sources for competency studies in the context of construction projects, and competencies such as alertness and quickness, experience and ethics have been identified [50-57]. The recently undertaken research on construction project managers' competencies (mainly with traditional delivery models) suggest that this research topic has remained popular during the recent decade [58-64]. Reviewing the relevant studies resulted in the identification of several literature-based competencies for project managers of traditional construction projects (see Appendix A). The following Figure 1 presents the top five competencies (in terms of ranking) listed in Appendix A. 


\begin{tabular}{|c|c|c|c|c|c|c|c|c|c|c|c|c|c|c|c|c|c|c|c|c|c|c|}
\hline Competency/Reference & 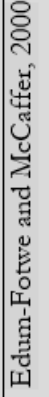 & 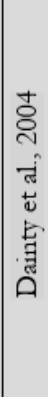 & 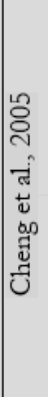 & 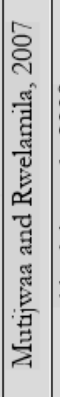 & 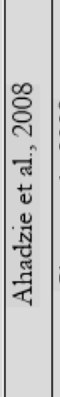 & 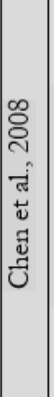 & 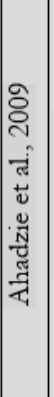 & 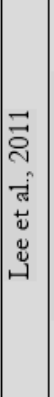 & 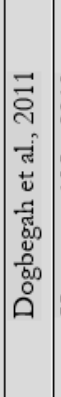 & 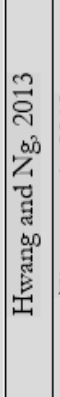 & 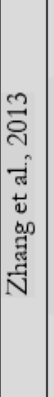 & 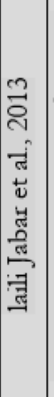 & 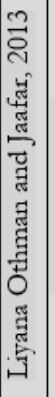 & 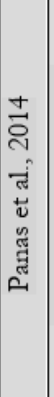 & 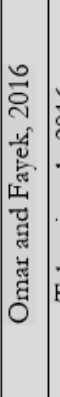 & 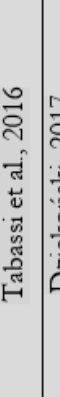 & 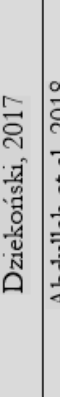 & 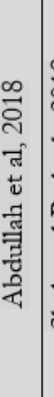 & 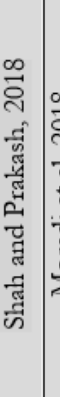 & 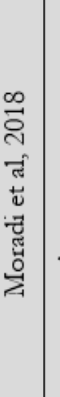 & 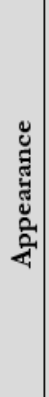 & 苞 \\
\hline Teamwork and cooperation & & $\checkmark$ & $\checkmark$ & & $\checkmark$ & & $\checkmark$ & $\checkmark$ & & & $\checkmark$ & & & & $\checkmark$ & & $\checkmark$ & & $\checkmark$ & & \multirow{2}{*}{9} & \multirow{2}{*}{1} \\
\hline Cost management & & & $\checkmark$ & $\checkmark$ & & & & $\checkmark$ & $\checkmark$ & $\checkmark$ & & & & & $\checkmark$ & & $\checkmark$ & $\checkmark$ & & $\checkmark$ & & \\
\hline Communication & & & $\checkmark$ & & & $\checkmark$ & & & $\checkmark$ & $\checkmark$ & & & & & $\checkmark$ & & $\checkmark$ & & $\checkmark$ & & 7 & 2 \\
\hline Leadership & & $\checkmark$ & $\checkmark$ & & & & & & & & $\checkmark$ & & & & $\checkmark$ & $\checkmark$ & & & & $\checkmark$ & \multirow{3}{*}{6} & \\
\hline Time management & & & & & $\checkmark$ & & $\checkmark$ & & & $\checkmark$ & & & & & $\checkmark$ & & $\checkmark$ & & $\checkmark$ & & & 3 \\
\hline Quality management & & & $\checkmark$ & & & & & $\checkmark$ & $\checkmark$ & & & & & & $\checkmark$ & & & $\checkmark$ & $\checkmark$ & & & \\
\hline Flexibility and adaptability & & $\checkmark$ & $\checkmark$ & & & & & & & & & & & & $\checkmark$ & & $\checkmark$ & & $\checkmark$ & & \multirow{9}{*}{5} & \\
\hline Resource management & & & & $\checkmark$ & & & & & $\checkmark$ & $\checkmark$ & & & & & $\checkmark$ & & & $\checkmark$ & & & & \\
\hline Knowledge of construction & & & & & $\checkmark$ & $\checkmark$ & $\checkmark$ & & & & & $\checkmark$ & & & & & & & $\checkmark$ & & & \\
\hline HSE & & & $\checkmark$ & & & & & $\checkmark$ & & & & & & & $\checkmark$ & & & $\checkmark$ & $\checkmark$ & & & \\
\hline Experience & $\checkmark$ & & & & & & & $\checkmark$ & & & & & $\checkmark$ & & & $\checkmark$ & $\checkmark$ & & & & & 4 \\
\hline Ethics & & & & & & & & & $\checkmark$ & & & & $\checkmark$ & & $\checkmark$ & & $\sqrt{ }$ & & $\checkmark$ & & & \\
\hline Problem solving & & & & & & & & & & & & $\checkmark$ & & $\checkmark$ & $\checkmark$ & & $\checkmark$ & & $\checkmark$ & & & \\
\hline Impact and influence & & $\checkmark$ & $\checkmark$ & & & & & $\checkmark$ & & & $\checkmark$ & & & & $\checkmark$ & & & & & & & \\
\hline Team management & & & $\checkmark$ & & & $\checkmark$ & & $\checkmark$ & & & & & & & $\checkmark$ & & & $\checkmark$ & & & & \\
\hline Project management & & & & $\checkmark$ & & & & & $\checkmark$ & & & $\checkmark$ & & & & & $\checkmark$ & & & & \multirow{5}{*}{4} & \multirow{5}{*}{5} \\
\hline Conflict management & & & & & $\checkmark$ & & $\checkmark$ & & & & $\checkmark$ & & & & & & $\checkmark$ & & & & & \\
\hline Achievement orientation & & $\checkmark$ & $\checkmark$ & & & & & & & & & & & & & & $\checkmark$ & & & $\checkmark$ & & \\
\hline Stakeholder management & & & & & & & & $\checkmark$ & & $\checkmark$ & & & & & $\checkmark$ & & & & & $\checkmark$ & & \\
\hline Decision-making & & & & & & & & & & & & & $\checkmark$ & $\checkmark$ & $\checkmark$ & & $\checkmark$ & & & & & \\
\hline
\end{tabular}

Figure 1. Project managers' competencies in traditional construction projects.

It looks obvious that project managers' behavior in their everyday work has been one of the important sources for understanding their competencies $[2,15,30,65]$. This viewpoint is selected in this study as well to address the subject of interest.

\subsection{The View of Standards of Practice on Project Managers' Competencies}

Four standards of practice have been identified as the sources addressing project managers' competencies. ICB.4(Individual Competence Baseline) explains the competency as the utilization of abilities, skills and knowledge for achieving the desired results, and presents project managers' 28 competencies in three groups of people, practice and perspective [66]. The PMCD (Project Manager Competency Development) framework introduces 16 competencies that are categorized in two groups, performance and personal competencies [67]. The APM (Association for Project Management) Body of Knowledge classifies project managers' 11 competencies in interpersonal and professional groups [68]. A framework, entitled PMI Talent Triangle, was introduced in the PMBOK (Project Management Body of Knowledge) Guide, in which three types of project managers' skills are presented [69] (see Table 1 for details). 
Table 1. Categorization of project managers' competencies by standards of practice.

\begin{tabular}{|c|c|c|}
\hline Standard & Group & Competency \\
\hline \multirow{3}{*}{ ICB.4 } & People & $\begin{array}{l}\text { (1) Self-reflection and self-management (2) Personal } \\
\text { integrity and reliability (3) Personal communication } \\
\text { (4) Relationships and engagement (5) Leadership (6) } \\
\text { Teamwork (7) Conflict and crisis (8) Resourcefulness } \\
\text { (9) Negotiation (10) Result orientation }\end{array}$ \\
\hline & Practice & $\begin{array}{l}\text { (1) Project design (2) Requirements and objectives (3) } \\
\text { Scope (4) Time (5) Organization and information (6) } \\
\text { Quality (7) Finance (8) Resource (9) Procurement (10) } \\
\text { Plan and control (11) Risk and opportunity (12) } \\
\text { Stakeholders (13) Change and transformation }\end{array}$ \\
\hline & Perspective & $\begin{array}{c}\text { (1) Strategy (2) Governance, structure and processes } \\
\text { (3) Compliance, standard and regulation (4) Power } \\
\text { and interest (5) Culture and values }\end{array}$ \\
\hline \multirow[t]{2}{*}{ PMCD.3 } & Performance & $\begin{array}{l}\text { (1) Project integration management (2) Project scope } \\
\text { management (3) Project time management (4) Project } \\
\text { cost management (5) Project quality management (6) } \\
\text { Project human resource management (7) Project } \\
\text { communication management (8) Project risk } \\
\text { management (9) Project procurement management } \\
\text { (10) Project stakeholder management }\end{array}$ \\
\hline & Personal & $\begin{array}{l}\text { (1) Communicating (2) Leading (3) Managing (4) } \\
\text { Cognitive ability (5) Effectiveness (6) Professionalism }\end{array}$ \\
\hline \multirow[t]{2}{*}{ APM } & Interpersonal & $\begin{array}{c}\text { (1) Communication (2) Conflict management (3) } \\
\text { Delegation (4) Influencing (5) Leadership (6) } \\
\text { Negotiation (7) Teamwork }\end{array}$ \\
\hline & Professionalism & $\begin{array}{l}\text { (1) Communities of practice (2) Competence (3) Ethics } \\
\text { framework (4) Leading and development }\end{array}$ \\
\hline \multicolumn{2}{|c|}{$\begin{array}{l}\text { PMI Talent Triangle } \\
\text { (PMBOK) }\end{array}$} & $\begin{array}{l}\text { (1) Technical project management skills (2) Leadership } \\
\text { (3) Strategic and business management skills }\end{array}$ \\
\hline
\end{tabular}

\section{Methodology}

\subsection{Research Design}

The research is undertaken to identify the competencies of project managers in the context of collaborative construction projects. Consequently, the research purpose here is descriptive, as it aims to portray the relevant competency profile. An important principle for the competency evaluation is the fit of competencies to the required characteristics and the job $[15,30]$. As explained earlier, the behavioral approach has been common for the competency studies, where frequency and type of individuals' (here the project managers') behavior in their everyday work is the main source for understanding their competencies. Thus, the self-evaluation of project managers' behavior is an efficient method of a competency study, because it is seen that a competency is a behavioral capability, and thus the project manager is the best evaluator of his/her behavior in the everyday work $[65,70]$. Accordingly, the survey strategy was employed to fulfill the intended purpose of this study, the approach of which is deductive, as there is a wealth of literature on project managers' competencies. According to Saunders et al. [71], "the survey strategy is popular and common in business and management research and is mainly utilized to answer who, what, where, how much and how many questions". Therefore, it is usually employed for conducting exploratory and descriptive studies. The popularity of surveys is mainly due to the possibility which they provide for collecting data in shorter periods of time and in a cost-effective manner [71]. 


\subsection{The Utilized Survey Technique}

The behavioral approach in competence research has acted as a starting point for the development of research techniques. Reviewing the literature on project managers' competencies in this study also led to the identification of a self-evaluation questionnaire. In this survey tool "Cycloid", by Evolute Technology (www.evolute.fi), the focus is on evaluating project managers' key behavioral competencies based on their current state (reality), target state (vision), and creative tension, which is the gap between personal vision and current reality $[65,72,73]$. If the reality and the vision are the same and there is no gap between them, there will be no motivation because of the lack of perceived need to move toward the vision. Accordingly, project managers' 30 behavioral competencies are evaluated through 60 linguistic statements (Appendix B), two statement per competency. This was performed by asking the respondents to select and determine the frequency of their behaviors in the situations presented by each linguistic statement on a scale of always/often/seldom/never in their current and target state. Evaluation of the frequency of these behaviors occurring in the representative statements of each competency was carried out both in the current and target states through analyzing the numeric values of the current and target states of the self-evaluation results.

\subsection{Theoretical Origin of the Competencies and Their Representing Statements in Cycloid}

These competencies and their representing linguistic statements originate from the research by Kirsi Liikamaa [74]. Later, these competencies have been categorized into two main groups and five subgroups [65] (Table 2).

Table 2. Project managers' behavioral competencies in Cycloid.

\begin{tabular}{ccc}
\hline Group & Subgroup & Competency \\
\hline \multirow{2}{*}{$\begin{array}{c}\text { Personal } \\
\text { Competencies }\end{array}$} & Self-awareness & $\begin{array}{c}\text { Emotional awareness, Self-assessment, } \\
\text { Self-confidence }\end{array}$ \\
\cline { 2 - 3 } & Self-control & $\begin{array}{c}\text { Trustworthiness, Maintaining order, } \\
\text { Flexibility, Innovation, Responsibility, } \\
\text { Seeking information, Production efficiency, } \\
\text { Decision quality, Stress tolerance }\end{array}$ \\
\cline { 2 - 3 } Social & Mognitive ability & $\begin{array}{c}\text { Analytical thinking, Conceptual thinking, } \\
\text { Language proficiency }\end{array}$ \\
\cline { 2 - 3 } Competencies & Empathy & $\begin{array}{c}\text { Achievement orientation, Commitment, } \\
\text { Initiative, Optimism }\end{array}$ \\
\cline { 2 - 3 } & Social skills & $\begin{array}{c}\text { Understanding others, Developing others, } \\
\text { Leveraging diversity, Organizational savvy }\end{array}$ \\
\hline & $\begin{array}{c}\text { Communication, Conflict management, } \\
\text { Management, Leadership, Relationship } \\
\text { building, Collaboration, Group capabilities }\end{array}$ \\
\hline
\end{tabular}

Liikamaa [65] undertook this categorization according to Goleman's [75] ontology of the five components of emotional intelligence at work, containing social competencies (social awareness and relationship management) and personal competencies (self-awareness, self-management and motivation). Several studies have employed Cycloid for evaluating project manager's competencies in various contexts $[2,65,72,76,77]$. Moreover, the competencies in Cycloid (listed in Table 2) were compared with identified competencies from the literature study (Figure 1 and Appendix A), and it became clear that the competencies in the Cycloid questionnaire are in line with the previous research on construction project managers' competencies. 


\subsection{Motivations for Choosing Cycloid}

Cycloid was selected for data collection in this study for six reasons. First, it has considerable theoretical support, and its content (30 behavioral competencies) is in line with the previous research on the competency subject in the context of construction projects. Second, it has a record for being utilized in numerous competency studies since 2006. Third, it provides the possibility of using the behavioral approach for the competency study in a reliable and highly economical way. Fourth, it was available in several languages (e.g., English, Finnish, Norwegian), thus making possible the collection of data from the respondents in their mother tongue. Fifth, its structure makes it possible to carefully evaluate the significance and frequency of project managers' different behaviors in their everyday job, representing their competencies, in the current state (reality) and target state (vision). Sixth, it can reveal the gap between the current and target state of the project managers' different behaviors, which in turn can be a useful source of information for the performance improvement.

\subsection{Data Collection}

The collection of data was undertaken through non-probability volunteer sampling. The sampling choice was based on three reasons: (i) there was no sampling frame available concerning the targeted population, (ii) there was no need for statistical inference from the sample, and (iii) data could be collected from the entire target population [71]. Accordingly, the questionnaire was sent to 33 project managers of recently completed or ongoing alliance and/or partnering construction projects in Finland and Norway. Finland and Norway were chosen for data collection because of their representativeness in terms of collaborative construction projects [2,78].

The categories of the studied construction projects comprise infrastructure (road and railway), institutional (hospital and school) and residential building (housing construction). In total, 24 questionnaires were completed (February-April 2020) and a response rate of $73 \%$ was achieved. Among respondents, $35 \%$ of them are/were working as the client's project manager and $65 \%$ of them as the contractor's project manager. Figure 2 presents the survey respondents' demographic information.

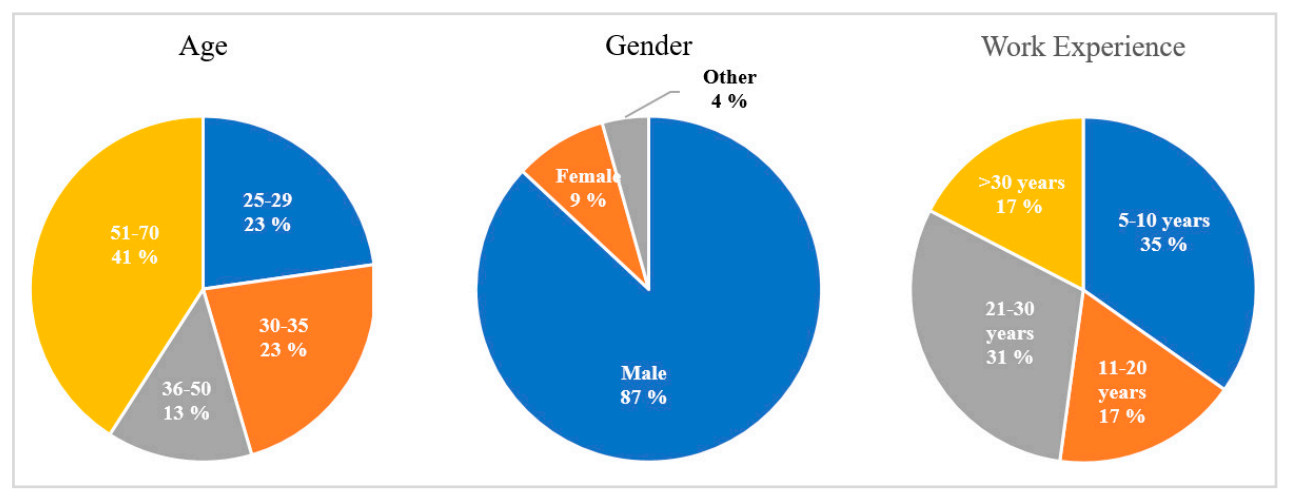

Figure 2. Demographic information of the survey respondents.

\subsection{Development of the Matrix Model of Competencies for Project Managers of Collaborative Construction Projects}

The research data portray the current state, the target state, and the creative tension of project managers' competencies in the context of collaborative construction projects. The analysis of these data formed a basis for the matrix model of competencies which answers the research question in this paper. The development of the matrix model was undertaken in three steps, and was based on two important aspects of competencies which were mentioned earlier: (i) contribution to successful performance, and (ii) difficulty of improvement. The following Figure 3 shows the process of developing the matrix model which is followed by an explanation of the process. 


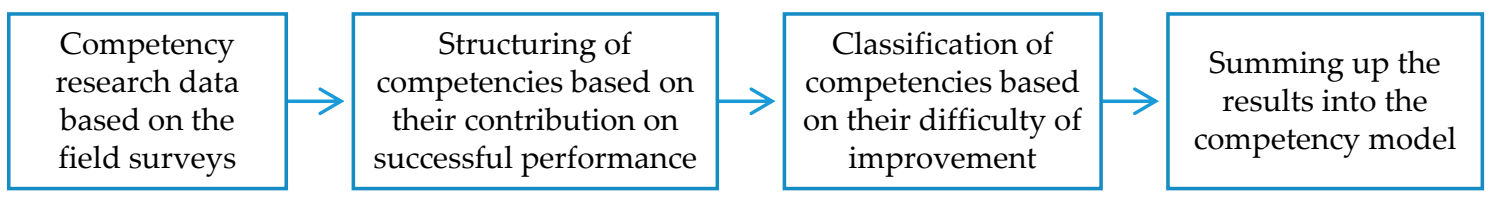

Figure 3. The research and development process behind the matrix model of competencies.

The first step was obtaining the competency research data (the significance of project managers' different competencies in the current state, target state and creative tension) through the conducted surveys in Norway and Finland, which were explained earlier. In the second step, the competencies were structured based on their contribution to project managers' successful performance. These structured competencies were those top 10 ones (in terms of the significance) in the target state, current state and creative tension of the respondent groups. The top 10 competencies in the target state and creative tension as well as current state are seen as the most important ones among the total 30 competencies for contributing toward the successful performance of the project managers. This structuring was performed through developing a three points scale (1-3), where:

- those competencies "common" in the "target state" of the "both respondent groups" were qualified as the highest (3);

- those competencies "common" in the "current state and creative tension" of the "both respondent groups" were qualified as the medium (2);

- those competencies "specific" in the "target state and/or creative tension" of "each respondent group" were qualified as the lowest (1). (See Table 3)

Table 3. Numeric values of the competencies based on their contribution to successful performance and difficulty of improvement.

\begin{tabular}{|c|c|c|c|c|c|c|c|}
\hline Competency & CSP & DAI & $\mathrm{CSP} \times \mathrm{DAI}$ & Competency & CSP & DAI & $\mathrm{CSP} \times \mathrm{DAI}$ \\
\hline Trustworthiness & 3 & 3 & 9 & Flexibility & 2 & 3 & 6 \\
\hline Stress tolerance & 3 & 3 & 9 & $\begin{array}{l}\text { Relationship } \\
\text { building }\end{array}$ & 1 & 1 & 1 \\
\hline $\begin{array}{c}\text { Conflict } \\
\text { management }\end{array}$ & 3 & 2 & 6 & $\begin{array}{l}\text { Leveraging } \\
\text { diversity }\end{array}$ & 1 & 1 & 1 \\
\hline Self-assessment & 3 & 2 & 6 & Maintaining order & 1 & 2 & 2 \\
\hline Initiative & 3 & 3 & 9 & Collaboration & 1 & 1 & 1 \\
\hline Optimism & 3 & 3 & 9 & Communication & 1 & 1 & 1 \\
\hline Group capabilities & 3 & 1 & 3 & $\begin{array}{c}\text { Achievement } \\
\text { orientation }\end{array}$ & 1 & 3 & 3 \\
\hline Decision quality & 2 & 2 & 4 & $\begin{array}{l}\text { Emotional } \\
\text { awareness }\end{array}$ & 1 & 3 & 3 \\
\hline $\begin{array}{l}\text { Understanding } \\
\text { others }\end{array}$ & 2 & 2 & 4 & $\begin{array}{l}\text { Language } \\
\text { proficiency }\end{array}$ & 1 & 1 & 1 \\
\hline $\begin{array}{l}\text { Production } \\
\text { efficiency }\end{array}$ & 2 & 1 & 2 & $\begin{array}{l}\text { Analytical } \\
\text { thinking }\end{array}$ & 1 & 2 & 2 \\
\hline Management & 2 & 1 & 2 & $\begin{array}{c}\text { Organizational } \\
\text { savvy }\end{array}$ & 1 & 2 & 2 \\
\hline Leadership & 2 & 1 & 2 & Responsibility & 1 & 3 & 3 \\
\hline
\end{tabular}


This developed scale represents the extent to which competencies contribute to the successful performance of the project managers. Therefore, it was entitled as CSP (contribution on successful performance). Table 3 presents the CSP values assigned to each competency.

The reason why common target state competencies were outweighed was that these competencies, as can be understood from the title, are the visionary and the most appropriate ones for project managers of collaborative construction projects. Moreover, the high overlap between the target state competencies of both the respondent groups was the second reason for the prioritization.

In the third step, the competencies were structured based on the degree to which project managers have difficulty in improving them. It was carried out by determining the difficulty of improvement of those competencies (structured in the first step) with high, medium and low contribution to successful performance of the project managers. A three-point scale (1-3) was then developed, where:

- the "most difficult to improve" competencies were qualified as "the highest point (3)";

- "somewhat difficult to improve" competencies were qualified as "the medium point (2)";

- "easy to improve" competencies were qualified as "the lowest point (1)".

This developed scale represents the extent to which project managers can improve their competencies. Therefore, it was entitled DAI (difficulty of improvement). Table 3 presents the DAI values assigned to each competency. This structuring of competencies was undertaken based on the relevant classifications made by Zwell [15] and Spencer and Spencer [30], whereby competencies related to skill and knowledge are relatively easy to develop, competencies related to motive and trait are hard to develop, and finally the competencies related to self-concept lie somewhere between and are somewhat hard to develop.

In the fourth step, the $3 \times 3$ matrix was developed based on the structuring of competencies in the previous steps. This was conducted by creating a table (see Table 3 ) and multiplying the CSP and DAI values of each competency and placing the competencies within the matrix accordingly. The definitions and behavioral indicators of the listed competencies in the model can be found in Appendix B.

\subsection{Limitations and Reliability of the Utilized Survey Technique}

Generally, "self-evaluation can be seen as an efficient and effective way for managing personal growth, developing oneself, clarifying roles, and committing to project-related tasks", [70,72]. However, there is a concern regarding this type of evaluation. It is less reliable for evaluating work performance [79], as people prefer to evaluate their own performance as the better one compared to others [80]. According to Refs. [72,81], "the effectiveness of self-evaluation can be better in evaluating the relationship between different items, such as competencies, than in comparing individuals' performance with each other".

Torrington and Hall [81] stated that "the effectiveness of this method depends on the content of the evaluation, the application method, and the organizational culture". In the selected approach for this study, the significance of different competencies in the current state and the target state were evaluated through statements related to the individual's everyday work. Individuals thus directly evaluated their own behavior instead of their own performance. Additionally, the futuristic viewpoint includes the concept of creative tension [73]. For this purpose, the self-evaluation presents an efficient way to reveal individuals' intentions and aspirations [72].

\section{Results}

The findings are presented in four groups. The first group presents the significance of project managers' various competencies in their current state. This is followed by presenting the 10 highest significant target state and creative tension competencies. Finally, Group 4 presents the matrix model of competencies for project managers of collaborative construction projects. 


\subsection{Group 1: The Current State of Project Managers' Different Competencies}

Table 4 presents Finnish and Norwegian project managers' highest significant competencies (top 10) in their current state.

Table 4. Highest significant competencies of project managers in the current state.

\begin{tabular}{cccc}
\hline \multicolumn{2}{c}{ Finnish Project Managers } & \multicolumn{2}{c}{ Norwegian Project Managers } \\
\hline Rank & Competency & Rank & Competency \\
1 & Trustworthiness & 1 & Trustworthiness \\
2 & Responsibility & 2 & Group capabilities \\
3 & Achievement orientation & 3 & Collaboration \\
4 & Stress tolerance & 4 & Initiative \\
5 & Leveraging diversity & 5 & Flexibility \\
6 & Optimism & 6 & Self-assessment \\
7 & Leadership & 7 & Optimism \\
8 & Group capabilities & 8 & Analytical thinking \\
9 & Initiative & 9 & Stress tolerance \\
10 & Flexibility & 10 & Leadership \\
\hline
\end{tabular}

Here, with Finnish project managers', trustworthiness was discovered as the highest significant competency, with the statements focusing on acting honestly and in an ethical manner, and admitting mistakes. The second highest ranked competency was responsibility, with the statements evaluating the ability of being responsible for the progress of one's own work and responsibility for common goals. The third highest one was achievement orientation, representing the ability of driving toward a high standard of excellence, and setting challenging goals and working hard to achieve them. The fourth highest one was stress tolerance, with the statements evaluating the capability to maintain performance when facing workload pressures and/or organizational impediments. The fifth highest one was leveraging diversity, with the statements focusing on the appreciative attitude towards others and respecting people from different backgrounds. Figure 4 presents different current state competencies of Finnish project managers in terms of the significance.

Regarding Norwegian project managers, it looks obvious that $70 \%$ of their highest significant competencies in the current state are the same as their Finnish colleagues (Table 4). This can be also a clue to the reliability and validity of this study. Another interesting point here is that trustworthiness competency has been discovered as the most significant in the current state of the both respondent groups, as trust-based relationships and cooperation in collaborative construction projects are crucial.

There are also some differences between the current state competencies of the two respondent groups. Collaboration, self-assessment and analytical thinking are three competencies in the current state of Norwegian project managers which are not present among the most significant competencies of Finnish project managers (Table 4). Concerning Finnish project managers, responsibility, achievement orientation and leveraging diversity are those highest-significant competencies which are not common with the current state competencies of Norwegian project managers. Figure 5 presents different current state competencies of Norwegian project managers in terms of their significance. 


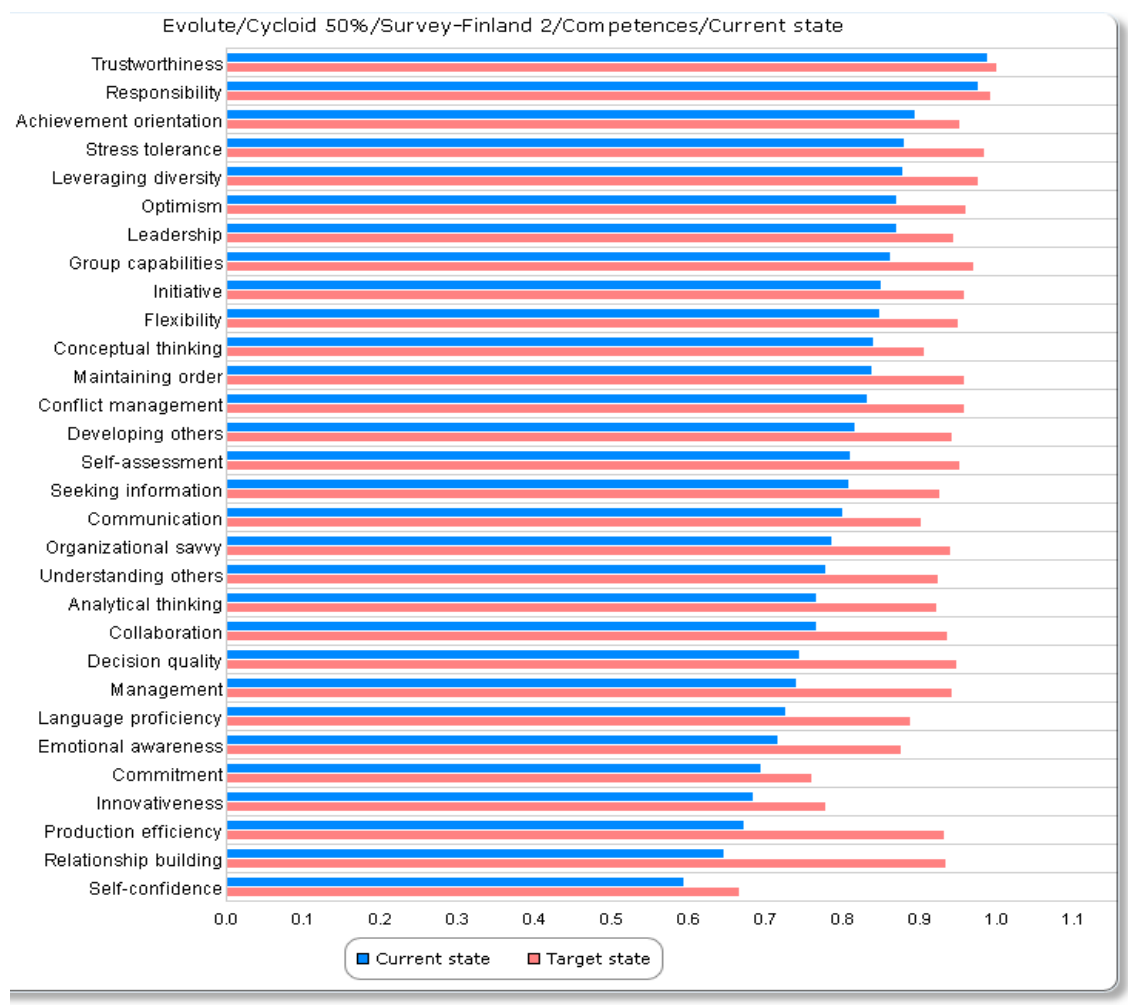

Figure 4. Competencies of Finnish project managers sorted according to their significance in the current state (blue bars).

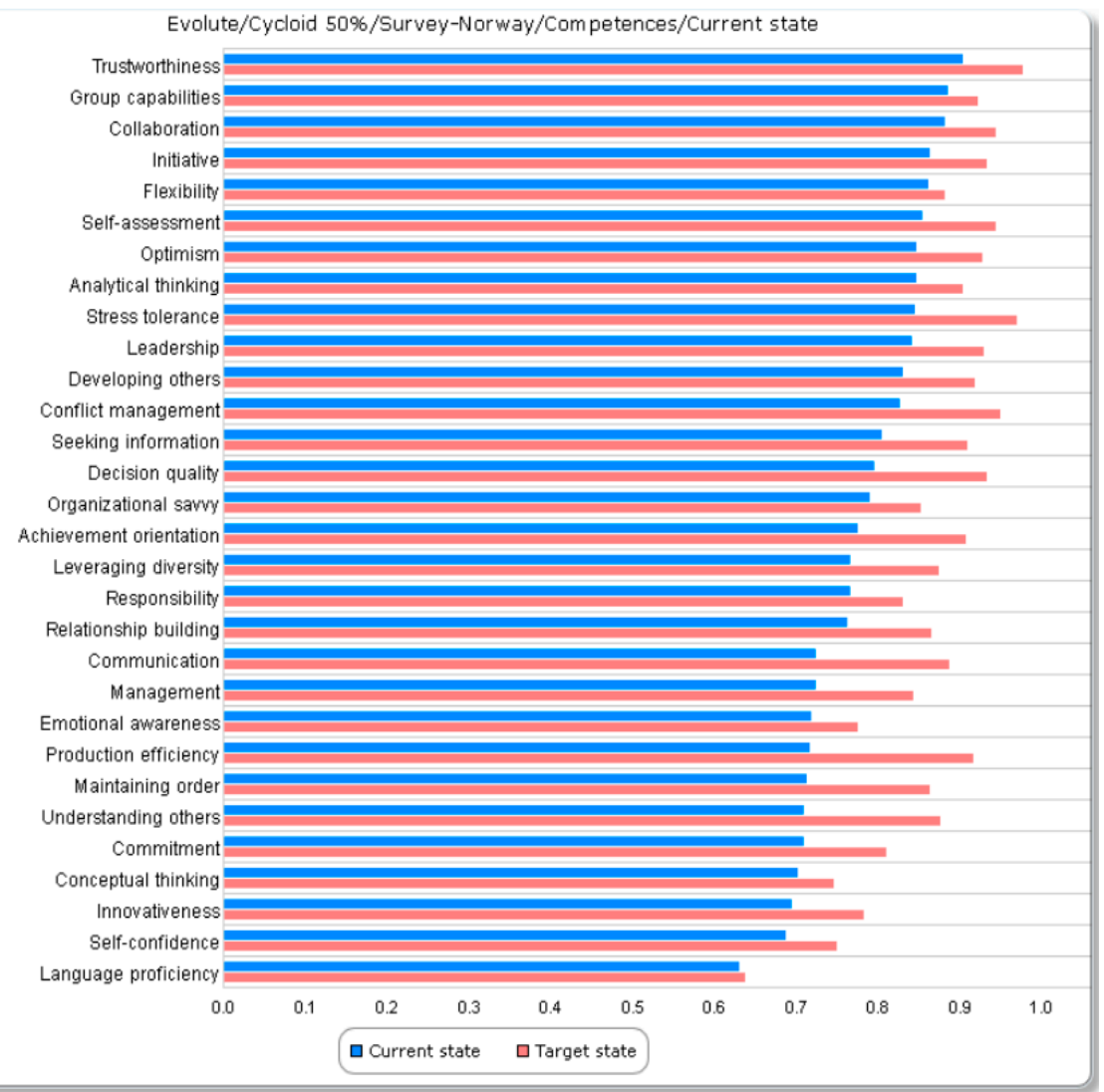

Figure 5. Competencies of Norwegian project managers sorted according to their significance in the current state (blue bars). 


\subsection{Group 2: The Target State of Project Managers' Different Competencies}

The following Table 5 presents the top 10 target state competencies (in terms of significance) of Finnish project managers for collaborative construction projects.

Table 5. Competencies of project managers in the target state.

\begin{tabular}{cccc}
\hline \multicolumn{2}{c}{ Finnish Project Managers } & \multicolumn{2}{c}{ Norwegian Project Managers } \\
\hline Rank & Competency & Rank & Competency \\
1 & Trustworthiness & 1 & Trustworthiness \\
2 & Responsibility & 2 & Stress tolerance \\
3 & Stress tolerance & 3 & Conflict management \\
4 & Leveraging diversity & 4 & Collaboration \\
5 & Group capabilities & 5 & Self-assessment \\
6 & Optimism & 6 & Initiative \\
7 & Maintaining order & 7 & Decision quality \\
8 & Conflict management & 8 & Leadership \\
9 & Initiative & 9 & Optimism \\
10 & Self-assessment & 10 & Group capabilities \\
\hline
\end{tabular}

There is $90 \%$ overlap for the five most significant competencies in the current and target states of Finnish project managers (see Tables 4 and 5). Group capabilities competency is the one which is not present among their top five current state competencies. This overlap suggests that the current competency profile of Finnish project managers in the addressed context is close to the ideal one in their target state. Figure 6 presents different target state competencies of Finnish project managers in terms of their significance.

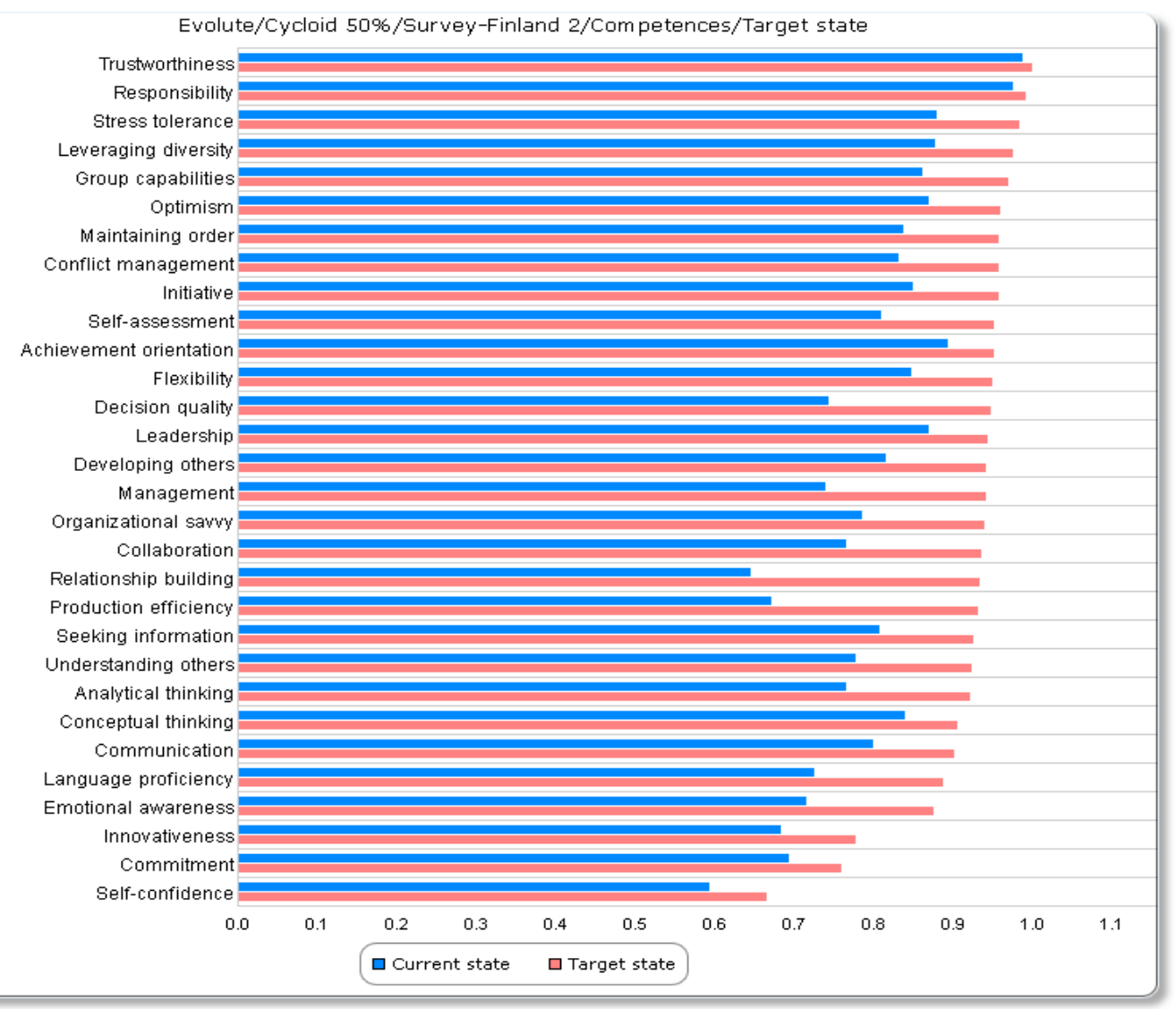

Figure 6. Competencies of Finnish project managers sorted according to their significance in the target state (red bars). 
Regarding Norwegian project managers, there is a high match $(80 \%)$ between their 10 most significant competencies in the current and target states (see Tables 4 and 5). Conflict management and decision quality are two competencies in their target state which are not present in the current state. Conflict management competency is related to project managers' capability to negotiate and resolve disagreements between people and to reach out for win-win situations. The statements representing decision quality competency evaluate project managers' ability to make decisions according to principles, purposes, and values. The mentioned overlap between Norwegian project managers' current and target state competencies indicates a considerable match between their current and the ideal (target) competency profile.

There is also a considerable match $(70 \%)$ between the 10 most significant competencies of Finnish and Norwegian project managers in their target state (Table 5). This identified overlap can be seen as an indication of the match between the obtained results from two different contexts, addressed in this study. This match, in turn, can provide a basis for developing a synthesis of the findings. Figure 7 presents different target state competencies of Norwegian project managers in terms of their significance.

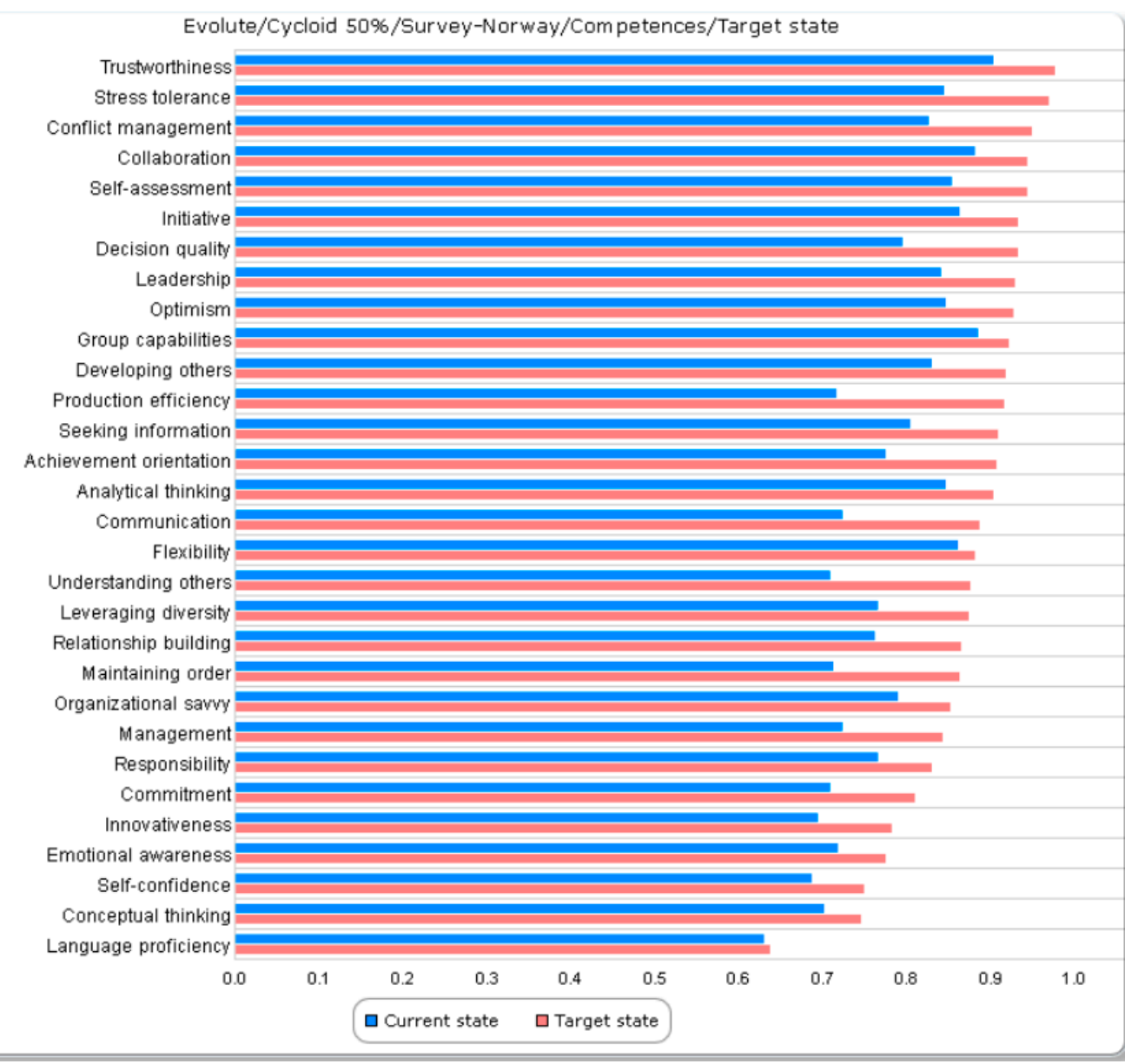

Figure 7. Competencies of Norwegian project managers sorted according to their significance in the target state (red bars).

\subsection{Group 3: The Creative Tension regarding Project Managers' Competencies}

Group 3 presents the competencies in which the greatest gap between the current state and the target state (creative tension) was identified (see Table 6). The mentioned gap shows the respondents' interest in improving their competencies. 
Table 6. Creative tension competencies of project managers.

\begin{tabular}{cccc}
\hline \multicolumn{2}{c}{ Finnish Project Managers } & \multicolumn{2}{c}{ Norwegian Project Managers } \\
\hline Rank & Competency & Rank & Competency \\
1 & Relationship building & 1 & Production efficiency \\
2 & Production efficiency & 2 & Communication \\
3 & Decision quality & 3 & Understanding others \\
4 & Management & 4 & Stress tolerance \\
5 & Collaboration & 5 & Conflict management \\
6 & Emotional awareness & 6 & Maintaining order \\
7 & Language proficiency & 7 & Decision quality \\
8 & Analytical thinking & 8 & Commitment \\
9 & Organizational savvy & 9 & Seeking information \\
10 & Understanding others & 10 & Achievement orientation \\
\hline
\end{tabular}

Finnish project managers are most interested in developing their relationship building (see Table 6). This competency was the second least significant in their current state and is related to project managers' ability to build and maintain friendly relationships with those contacts which are or might be useful for realizing work-related goals. This amount of creative tension toward this competency is understandable, as trust-based relationships are one of the main success factors for collaborative construction projects. The second competency of interest here is production efficiency, wherein the statements concentrated on the ability of performing tasks quickly and according to high standards. This competency was evaluated as the third least significant in the current state (see Figure 4). The third highest creative tension was identified for the competency of decision quality. This is followed by the management competency (see Figure 8), which also was among the 10 least significant competencies in the current state.

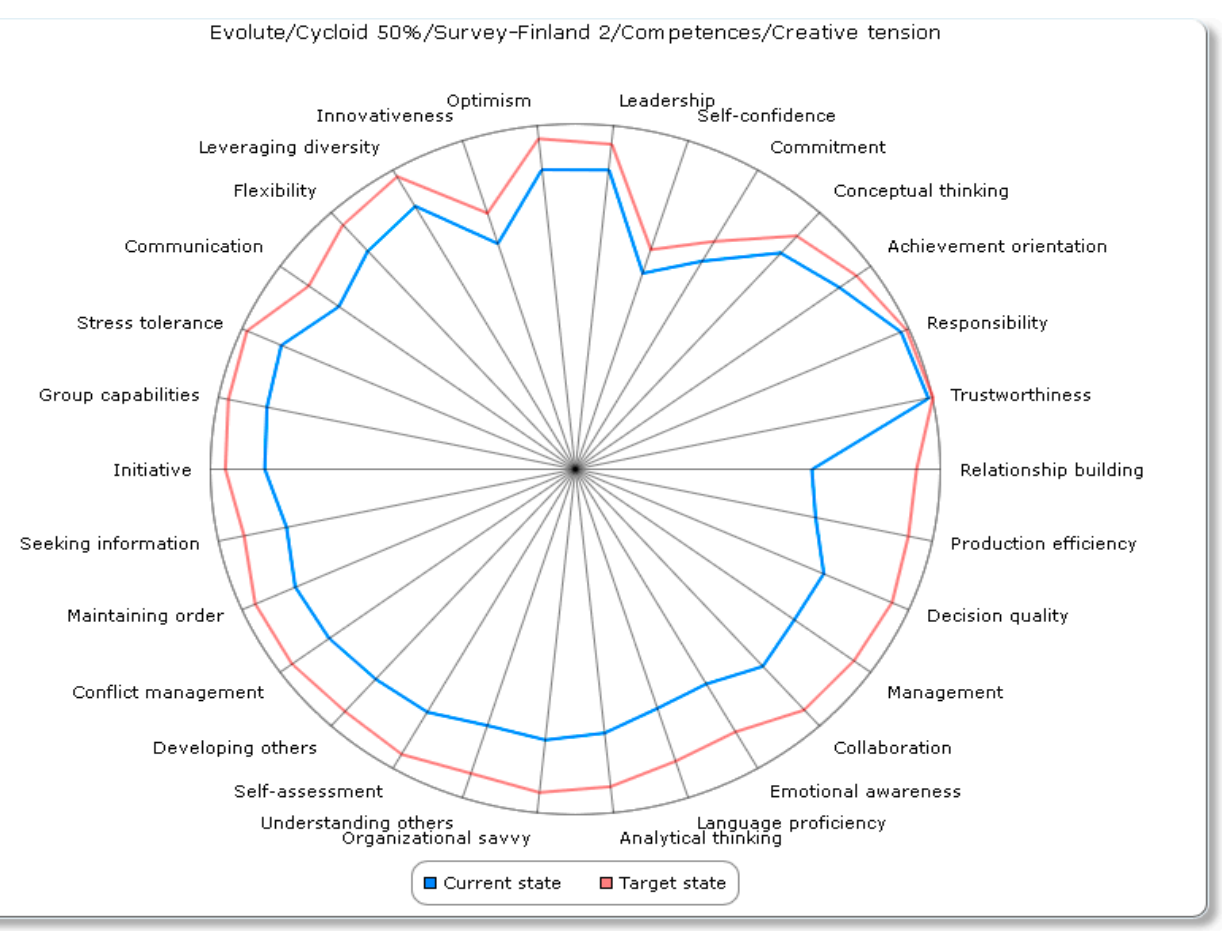

Figure 8. Creative tension competencies of Finnish project managers.

It is worth mentioning that the common competencies in the current state and in the target state of Finnish project managers are not present among their top 10 creative tension competencies. This can be a message that they need complementary competencies (those 
highly significant ones in their creative tension), in addition to the target state ones, to support their successful performance.

Norwegian project managers, like their Finnish colleagues, have the most willingness to improve and develop further their production efficiency competency (see Table 6). Communication competency was evaluated as the second highest here, which points to the ability to listen to others, to openly express one's feelings, ideas and opinions, and to read non-verbal cues. Understanding others' competency was the third highest in this category, with the statements focusing on project managers' capability to notice other individuals' feelings and perspectives. Stress tolerance is the next competency, which was also among the 10 highest ones in their current state. This can be a clue that Norwegian project managers of collaborative construction projects deal with considerable amounts of stress in their everyday work. The fifth competency which Norwegian project managers have high amounts of willingness to improve was conflict management (see Table 6 and Figure 9).

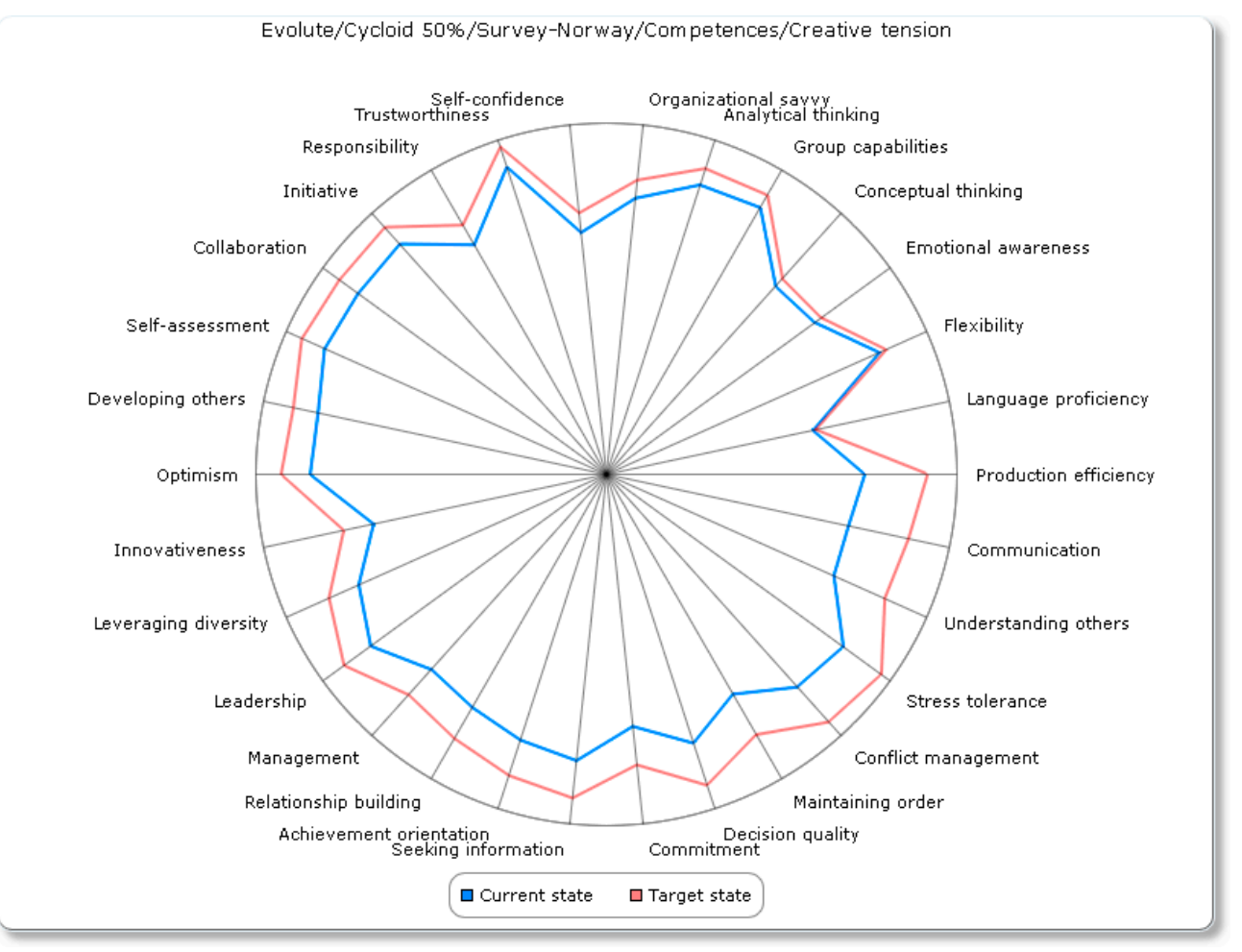

Figure 9. Creative tension competencies of Norwegian project managers.

Table 7 presents the differences, labeled "unique", and similarities, labeled "same for all", between the creative tension competencies of the two respondent groups (see Table 6) for improving their competencies.

Unlike the current state and target state, there are several differences between the viewpoints of the two respondent groups. The ranking of the competencies listed in Table 7 was developed based on the median of the ranking in the creative tension of the two respondent groups (Table 6). Those competencies with the same rank in both respondent groups have been listed alphabetically. 
Table 7. Similarities and differences between creative tension competencies of Finnish and Norwegian project managers.

\begin{tabular}{|c|c|c|}
\hline Rank & Competency & Same for All or Unique \\
\hline 1 & Production efficiency & \multirow{3}{*}{ Same for all } \\
\hline 2 & Decision quality & \\
\hline 3 & Understanding others & \\
\hline 1 & Relationship building & \multirow{9}{*}{ Unique } \\
\hline 2 & Communication & \\
\hline 3 & $\begin{array}{l}\text { Management } \\
\text { Stress tolerance }\end{array}$ & \\
\hline 4 & $\begin{array}{c}\text { Collaboration } \\
\text { Conflict management }\end{array}$ & \\
\hline 5 & $\begin{array}{l}\text { Emotional awareness } \\
\text { Maintaining order }\end{array}$ & \\
\hline 6 & Language proficiency & \\
\hline 7 & $\begin{array}{l}\text { Analytical thinking } \\
\text { Commitment }\end{array}$ & \\
\hline 8 & $\begin{array}{l}\text { Organizational savvy } \\
\text { Seeking information }\end{array}$ & \\
\hline 9 & Achievement orientation & \\
\hline
\end{tabular}

\subsection{Group 4: Matrix Model of Competencies}

This matrix model presents project managers' competencies for collaborative construction projects. The model was developed for classifying and grouping competencies according to their nature, i.e., characteristics of importance.

For this purpose, competencies were structured based on the following: Contribution to project managers' successful performance (vertical axis), and the Degree of difficulty to improve those competencies (horizontal axis) (see Table 3 for details). This structuring, as can be seen in Figure 10, resulted in discovering key competencies, supportive competencies, hybrid competencies and threshold competencies based on which the matrix was divided into four sets.

Among the key competencies, trustworthiness, stress management, initiative and optimism were common in the target state of both the respondent groups. This means that these competencies considerably contribute toward the successful performance of the project managers. In addition, these four competencies are hard to improve, as they are more hidden and central to personality. The last competency in this group is flexibility, which was common in the current state competencies of Finnish and Norwegian respondents. This competency is also hard to improve, but its contribution to successful performance is lesser than the four ones described earlier.

The key competencies, altogether, are hard to improve while contributing to the successful performance of the project managers. Therefore, the most cost-effective way for the employers is to select those project managers for collaborative construction projects that already have these competencies. The definition and behavioral indicators of the presented competencies within the model in Figure 10 can be found in Appendix B.

The supportive competencies are easier to develop, as they are knowledge and skilloriented. In terms of contribution to successful performance, the relevance of group capabilities competency is higher than others in this group. Training is the best means of improving the supportive competencies, which can be considered for improving the performance of the existing project managers. 


\section{Competency Model for Project Managers of Collaborative Construction Projects}

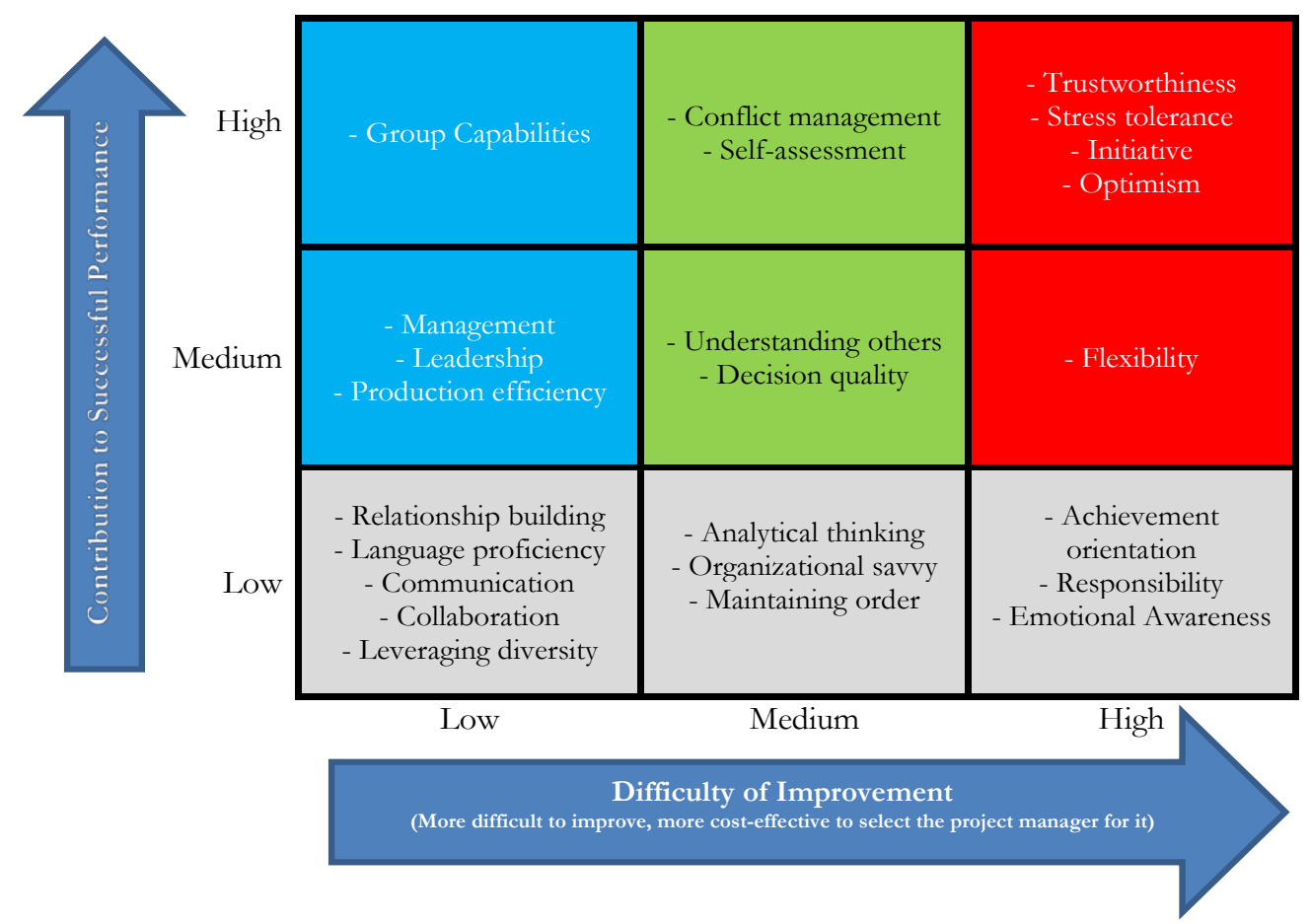

Legend

\begin{tabular}{|c|c|}
\hline Key Competencies & $\begin{array}{l}\text { Those competencies to be considered by employers for selecting the project } \\
\text { managers, as they are hidden and central to personality and considerably } \\
\text { contribute toward the successful performance of project managers. }\end{array}$ \\
\hline $\begin{array}{c}\text { Supportive } \\
\text { Competencies }\end{array}$ & $\begin{array}{l}\text { Those competencies to be considered by project managers for performance } \\
\text { improvement, as they can be improved easier by training and also contribute } \\
\text { toward the successful performance of project managers. }\end{array}$ \\
\hline Hybrid Competencies & $\begin{array}{l}\text { Those competencies to be considered by both project managers and their } \\
\text { employers. These competencies considerably contribute to successful } \\
\text { performance, and it is neither too difficult nor too easy to improve them. }\end{array}$ \\
\hline $\begin{array}{c}\text { Threshold } \\
\text { competencies }\end{array}$ & $\begin{array}{l}\text { Those competencies needed for minimally accepted level of work, the lower cut } \\
\text { off point below which a project manager of a collaborative construction project } \\
\text { would not be considered competent. }\end{array}$ \\
\hline
\end{tabular}

Figure 10. Matrix model of competencies for project managers of collaborative construction projects.

The hybrid competencies are somewhat difficult to improve, but they also significantly contribute toward the successful performance of project managers. Accordingly, these competencies, with dual functionality, can be considered for both the selection of project managers of relevance and for improving the performance of the existing ones.

Finally, the threshold competencies are those ones which seem to make less contribution to successful performance (compared to the previously explained groups). These competencies are required for the minimally accepted level of work, the lower cut off point below which a project manager of a collaborative construction project would not be considered competent.

\section{Discussion}

The first and second groups of results showed considerable matches between the current state competencies of both the respondent groups as well as their target state competencies (Tables 4 and 5). Project managers of collaborative construction projects, as the leaders, need to establish cooperation between project team members based on trust-based relationships for the good of the project [2,5]. Such an achievement by the project manager requires competencies such as trustworthiness, stress management, conflict 
management, and groups capabilities, as have been identified in this study. Moreover, the manager of a project with a single co-located team, jointly developing and validating goals and controlling the project, needs to know his or her strengthens and weaknesses (selfassessment competency) to effectively contribute toward project development and control. Additionally, such a project manager should be able to see the different opportunities and seize them (initiative competency) for the good of the project. Finally, the project manager needs to be determined to achieve the goals of the project regardless of the setbacks and/or organizational impediments (optimism competency).

The third group of results presented the creative tension competencies of the project managers, wherein there were some similarities between the viewpoints of the two respondent groups. Both Finnish and Norwegian project managers prefer to improve their production efficiency, understanding of others, and decision quality competencies. Throughout every collaborative construction project, in the design and construction processes, there are a series of internal suppliers and customers [6]. "These relationships are often implicit rather than explicit, and there is a very long chain of events starting with planning and design, where information is built on information, while in construction, material is built upon material", [6]. The project manager of such a collaborative environment needs to perform his or her tasks quickly and according to high standards (production efficiency competency) and make reliable decisions based on principles, purpose and values (decision quality competency) in order to be a successful supplier for his/her customers (team members). Such a project manager also needs to sense the feelings and perspectives of other people (understanding others' competency) to be able to build and maintain effective relationships with his/her team members.

Unlike the target state competencies, there are several differences between the creative tension competencies of the two respondent groups, which are understandable, as some features of collaborative construction projects are unique and context-oriented, e.g., culture, contracting parties. For instance, leveraging diversity and language proficiency are two competencies, which Finnish project managers have high willingness to improve, but there is no such desire in Norwegian project managers. One reason for these interests in Finland can be the fact that the usage of English language and the presence of foreign experts in the Finnish construction industry have been considerably increased in the last two decades [2]. Therefore, these uncommon and specific creative tension competencies of each respondent group can be considered for the performance improvement of project managers in the relevant context.

The differences and overlaps mentioned earlier can be seen as a basis to argue that the elements of collaborative construction projects affect the required competencies for the successful performance of project managers. This means that the common elements, e.g., trust-based relationships and shared risk/reward systems, require certain core competencies, whereas the unique elements, e.g., culture and contracting parties, require context-oriented competencies. The developed hypothesis needs to be tested in future studies. However, it seems to be somewhat in line with the prior project contingency research $[14,37,82]$, where it has been shown that different types of projects need project managers with certain types of competencies.

Finally, the last group of results presented a novel matrix model of competencies for project managers of collaborative construction projects. The novelty of this model is related to its functions and features. This model not only presents the cost-effective method (easier to improve competencies) for performance improvement of the existing project managers, but also provides new insights for employers of the project managers to know which competencies are difficult to improve and contribute to the successful performance. This also provides the cost-effective way for employers to select the right project manager for their collaborative construction project. These functions of the model are based on its two important features: addressing the contribution of competency to the successful performance, and difficulty of the improvement. This model provides new insights into the importance of the human side of project management in collaborative construction projects. 
The findings can also intensify the interest in potential future research on the competencies of all the project team members in collaborative construction projects.

The findings of this study, in the big picture, present a novel conceptual perspective (the matrix model) toward project managers' competencies. The focus of this different perspective is on two important aspects of competencies (contribution to successful performance and difficulty of improvement) which have been very limitedly addressed in the previous competency studies in an integrated manner. Moreover, addressing the subject of interest in the context of collaborative construction projects contributes toward the body of knowledge on project managers' competencies. This contribution was accomplished through identifying those competencies which project managers of collaborative construction projects need to possess to succeed. As the implications of this research, it can be stated that project managers and their employers in collaborative construction projects need to be aware of those easy to improve and hard to improve competencies which make the greatest contribution to the successful performance. Those employers can use key, supportive and hybrid competencies (presented in this research) to recruit the right person for their projects and improve the performance of their current project managers.

\section{Conclusions}

The purpose of this study was to identify project managers' most important competencies for collaborative construction projects, which finally led to the development of a matrix-form competency model. This model has an explanatory capacity for structuring various competencies in a novel manner that can be useful for individual project managers together with organizations in charge of collaborative construction projects. The following conclusions concerning project managers of collaborative construction projects (particularly in Finland and Norway) are based on the obtained results:

- Elements of collaborative construction projects can affect the required competencies for the successful performance of project managers. The common elements, e.g., trust-based collaboration and cooperation, shared risk-reward system, require certain core competencies, whereas the unique elements, e.g., culture and contracting parties, require certain context-oriented competencies;

- The profile of the project managers' competencies, in the big picture, represents individual efficiency and effectiveness, combined with teamwork, mutual understanding and trust, collaborative cooperation, and no-blame-related behavior;

- Trustworthiness, stress tolerance, initiative, optimism and flexibility competencies are cost-effective criteria for recruiting the project managers;

- Group capabilities, management, leadership and production efficiency competencies represent sources for the performance improvement of the existing project managers;

- Conflict management, self-assessment, decision quality and understanding others competencies are sources for both the selection of the project managers and improving the performances of the existing ones;

- The 11 threshold competencies (presented in Figure 10), required for the minimally accepted level of work, represent the lower cut off point below which the project manager would not be considered competent.

These findings contribute to the body of knowledge on project managers' competencies through providing academic and practical insights for competence-based selection and performance improvement of the project managers in the context of collaborative construction projects. The generalizability of the findings of this study is still rather limited. The research is based on input from professionals in Norway and Finland, but the challenges and issues discussed in the paper are of a general nature, relevant well beyond the Nordic countries. As with all new concepts, the matrix model of competencies needs validation in other contexts before consideration as a generally accepted model. Therefore, further studies in various regions and business conditions are a potential area for further research. The obtained results provide a basis for the following research areas, which can form starting points for the future studies: 
- How to select project managers of collaborative construction projects based on the presented categories in the matrix model, developed in this study;

- How to train competencies in those different categories;

- How to develop a frame of reference for successful/superior performance of project managers in collaborative construction projects;

- How to adapt the developed competency model in this study to other sectors of construction projects;

- Although this study found no fundamental differences in the viewpoints of different age groups among the survey respondents, more detailed analysis on the potential impact of project managers' experience/age can be considered as an area for further relevant research.

Author Contributions: Conceptualization, S.M.; methodology, S.M.; software, S.M.; validation, S.M.; formal analysis, S.M.; investigation, S.M.; resources, S.M.; data collection, S.M.; writing—original draft preparation, S.M.; writing-review and editing, S.M., K.K., K.A. and O.J.K.; visualization, S.M.; supervision, K.K., K.A. and O.J.K. All authors have read and agreed to the published version of the manuscript.

Funding: This research received no external funding.

Institutional Review Board Statement: Not applicable.

Informed Consent Statement: Not applicable.

Data Availability Statement: The data presented in this study are available on request from the corresponding author. The data are not publicly available due to privacy and ethical restrictions.

Conflicts of Interest: The authors declare no conflict of interest.

\section{Appendix A}

Project managers' competencies in construction projects, identified from the literature.

\begin{tabular}{ccc}
\hline Competency & Reference & Appearance \\
\hline Teamwork and cooperation & {$[16,19,20,23,46,47,52,61,63]$} & 9 \\
Cost management & {$[10,12,22,47,52,54,61-63]$} & 7 \\
\hline Communication & {$[21-23,47,54,61,63]$} & \\
\hline Leadership & {$[16,46,47,62-64]$} & 6 \\
Time management & {$[19,20,23,54,61,63]$} & \\
Quality management & {$[10,22,23,47,52,63]$} & \\
Knowledge of construction & {$[19-21,23,55]$} & 5 \\
Flexibility and adaptability & {$[23,46,47,61,63]$} & \\
Resource management & {$[10,12,22,54,63]$} & \\
HSE (health, safety and & {$[10,23,47,52,63]$} & \\
environment) & {$[36,52,56,61,65]$} & \\
Experience & {$[22,23,56,61,63]$} & \\
Ethics & {$[13,23,55,61,63]$} & \\
Problem solving & {$[16,46,47,52,63]$} & \\
Impact and influence & {$[10,21,47,52,63]$} & \\
Team management & {$[12,22,55,61]$} & \\
Project management & {$[46,47,61,62]$} & \\
Achievement orientation & {$[16,19,20,61]$} & \\
Conflict management & {$[52,54,62,63]$} & \\
Stakeholder management & {$[22,23,61,63]$} & \\
Innovation & {$[13,56,61,63]$} & \\
Decision-making & {$[46,47,61,63]$} & \\
Analytical thinking & & \\
& & \\
\hline
\end{tabular}




\begin{tabular}{|c|c|c|}
\hline Risk management & {$[22,54,63]$} & \multirow{8}{*}{3} \\
\hline Procurement management & {$[10,61,63]$} & \\
\hline Initiative & {$[46,47,63]$} & \\
\hline Information seeking & {$[23,46,47]$} & \\
\hline Scope management & {$[47,61,63]$} & \\
\hline Motivation & {$[23,61,63]$} & \\
\hline Negotiation & {$[23,61,63]$} & \\
\hline Commitment & {$[23,62,63]$} & \\
\hline Developing others & {$[47,63]$} & \multirow{12}{*}{2} \\
\hline Conceptual thinking & {$[46,47]$} & \\
\hline Planning & {$[21,54]$} & \\
\hline Directiveness & {$[46,47]$} & \\
\hline Change management & {$[16,23]$} & \\
\hline Project integration management & {$[62,63]$} & \\
\hline Assertiveness & {$[23,61]$} & \\
\hline Self-control & {$[23,63]$} & \\
\hline Reliability & {$[23,63]$} & \\
\hline Relationship building & {$[16,21]$} & \\
\hline Interpersonal understanding & {$[16,63]$} & \\
\hline Customer focused & {$[46,47]$} & \\
\hline Self-confidence & [61] & \multirow{23}{*}{1} \\
\hline Tendering & [12] & \\
\hline Knowledge management & [47] & \\
\hline Operation management & [12] & \\
\hline Estimating & [12] & \\
\hline General business management & [12] & \\
\hline Judgment & [52] & \\
\hline Professionalism & [52] & \\
\hline Management & [52] & \\
\hline Alertness and quickness & [56] & \\
\hline Organizational awareness & [16] & \\
\hline Ability to deal with stress & [61] & \\
\hline Ability to formulate goals & [61] & \\
\hline Sensitivity & [23] & \\
\hline Cultural competence & [63] & \\
\hline Mental agility & [23] & \\
\hline Positive outlook & [23] & \\
\hline Consciousness & [23] & \\
\hline Learning oriented & [23] & \\
\hline Empathy and Aspiration & [61] & \\
\hline Emotional resilience & [23] & \\
\hline High energy level & [23] & \\
\hline Information technology skills & [23] & \\
\hline
\end{tabular}




\section{Appendix B}

Competencies with their definitions and representing linguistic statements in Cycloid.

\begin{tabular}{|c|c|c|}
\hline Competency & Definition & Statement \\
\hline Emotional awareness & The ability to recognize, understand and analyze one's own feelings. & $\begin{array}{l}\text { I recognize the factors that have caused a certain emotional } \\
\text { reaction. }\end{array}$ \\
\hline \multirow{2}{*}{ Self-confidence } & \multirow{2}{*}{$\begin{array}{l}\text { A sense of one's self-worth and capabilities. The ability to present and } \\
\text { defend one's opinion. }\end{array}$} & $\begin{array}{l}\text { I prefer to behave in accordance with external influences rather } \\
\text { than in accordance with my own point of view. }\end{array}$ \\
\hline & & $\begin{array}{l}\text { It is difficult for me to defend my own opinion when other people } \\
\text { disagree. }\end{array}$ \\
\hline \multirow{2}{*}{ Trustworthiness } & \multirow{2}{*}{$\begin{array}{l}\text { To deliver on promises. Keep schedules, arrive on time on meetings } \\
\text { and complete work as agreed. Maintain trust between people. }\end{array}$} & I act honestly and in an ethical manner \\
\hline & & Instead of covering up my mistakes I admit them. \\
\hline \multirow{2}{*}{ Maintaining order } & \multirow{2}{*}{ Concern for order, quality and accuracy } & I check my work once more before handing it in. \\
\hline & & I work systematically and effectively. \\
\hline \multirow[t]{2}{*}{ Innovativeness } & \multirow{2}{*}{$\begin{array}{l}\text { Natural and open attitude towards new ideas, attitudes and } \\
\text { information }\end{array}$} & $\begin{array}{l}\text { I would rather adhere to established ways of action than to try } \\
\text { something new. }\end{array}$ \\
\hline & & I like to solve the encountered problems in new and unique ways. \\
\hline \multirow[t]{2}{*}{ Responsibility } & \multirow[t]{2}{*}{$\begin{array}{l}\text { Be responsible for the progress of one's own work. Take responsibility } \\
\text { of own mistakes. The feeling of responsibility over common goals. }\end{array}$} & $\begin{array}{l}\text { I complete my tasks conscientiously even if nobody is supervising } \\
\text { me. }\end{array}$ \\
\hline & & It is difficult for me to keep my promises. \\
\hline \multirow[t]{2}{*}{ Seeking information } & \multirow{2}{*}{ The curiosity to know more about things, people or issues. } & $\begin{array}{l}\text { If I am not satisfied with the facts presented to me, I get in touch } \\
\text { with outsiders to obtain some background information. }\end{array}$ \\
\hline & & $\begin{array}{l}\text { I am curious and I collect information from my environment that } \\
\text { could be of use in the future. }\end{array}$ \\
\hline
\end{tabular}


Analytical thinking

The use of logical, systematic reasoning to understand, analyze, and the ability to discern causal relationships. resolve problems. The ability to break problems into smaller pieces and

In problem situations I break down the problem into smaller sub-problems.

I prepare in advance for foreseeable problems by thinking about different solutions to them

The ability to use models, theories or frameworks to interpret or to

explain events. The ability to identify patterns and to the see the "big picture".

Conceptual thinking

Language proficiency

Ability and courage to use foreign languages

The drive towards a high standard of excellence. Setting challenging goals and working hard to achieve them.

Achievement orientation

Initiative

The ability to see new possibilities and to seize opportunities. To do more than what is expected.

Optimism

Pursuing goals regardless of obstacles and setbacks.

The ability to sense the feelings and perspectives of other people.

Understanding others

abilities.
ating
I use 'rules of thumb' or common sense to solve problems.

I aim to simplify complex situations by combining issues.
I do not hesitate to use my language skills in my work tasks.

I develop my working methods to improve my performance.

When performing a task I always do my best to guarantee as good a result as possible.

I consciously behave in a way that creates new opportunities and minimizes possible problems.

I act quickly and determinedly whenever opportunities and crises appear. (arise)

I believe that people do the right things if they are given the possibility.

I believe in achieving my goals despite obstacles and setbacks

I notice hints of other people's feelings and I am able to read between the lines.

I actively listen and seek hints of other people's feelings and intentions to understand their earlier behavior.

I pursue the development of others by delegating suitable and challenging tasks to them, and by giving them the authority needed to perform the tasks.

Developing others Noticing other people's needs for development and promotion of their

I give constructive feedback which is not directed at the person himself/herself but at his/her doings. 
Communication

Management

The ability of controlling things and people. reach out for win-win situations.
I find it difficult to express myself or to say my opinion.

The ability to listen to others. The ability to openly express one's feelings, ideas and opinions. The ability to read non-verbal cues.

The ability to negotiate and resolve disagreements between people. To

apposite questions to understand him/her better.

encourage others to discuss matters constructively and openly in order to find a solution to a problem.

I aim to arrive at solutions by which everybody wins.

When assigning a task, I give adequate directions and make clear both the objectives and requirements.

I evaluate other people's performance and achievements and compare them with the targets.

Leadership

Management activities that are centered upon human beings.

treat group members impartially and fairly.

I act in a way as to (inspire and commit others) make other people enthusiastic and committed to the group's tasks.

I maintain contacts that I can make use of when the situation requires.

Relationship building Building or maintaining friendly relationships or networks of contacts with people who are or might be useful in achieving work-related goals.

I experience establishing new relationships difficult and displeasing.

I act in a way that creates a climate encouraging cooperation.

I recognize possibilities to cooperate and I try to maintain them through my own activities.

Collaboration

Working together with others towards common goals.

The comprehension of one's own limits and strengths.

I am familiar with my strengths and weaknesses.

I analyze my actions and learn from my experiences.

I am open to new ideas, approaches and data (information).

Flexibility

The ability to manage multiple demands without losing focus. The ability to handle the ambiguities of organizational life. To be open to new experiences and viewpoints.
It is difficult for me to adapt to the changes in my working environment. 
Stress tolerance

To maintain performance when facing workload pressures and or organizational impediments.
The level of my performance weakens when I work under pressure or when stressed.

I can handle tasks and situations that are unpleasant and stressful.

I act according to the way determined by my environment and I respect the organizational norms.

Commitment

Adopting the goals of the group or organization.

My own objectives differ from the objectives of the group.

I organize my tasks in a way that speeds up their accomplishment.

I delegate tasks and utilize resources efficiently even if they would be (are) scarce.

Decision quality Making decisions based on principles, purposes and values.

In my decisions I take into account problems which may arise. I foresee the implications of different options.

I see diversity as an opportunity, and I try to create an environment where diverse people can thrive.

Leveraging diversity

Appreciative attitude towards others. Respecting people from different backgrounds.

I am biased against people because of their backgrounds.

Organizational savvy

Understanding and utilizing organizational dynamics in order to achieve objectives.

Group capabilities

the capability of working cooperatively with others, to be part of a team, to work together, as opposed to working separately or competitively.
I recognize the current culture and atmosphere of the organization.

I use formal and informal communication channels efficiently.

It is difficult or unpleasant for me to encourage and motivate other people.

In a team, I act in a way that creates friendship and team spirit between the group members. 


\section{References}

1. Forbes, L.H.; Ahmed, S.M. Modern Construction: Lean Project Delivery and Integrated Practices; CRC Press: Boca Raton, FL, USA, 2010.

2. Moradi, S.; Kähkönen, K.; Aaltonen, K. Project Managers' Competencies in Collaborative Construction Projects. Build. J. 2020, 10, 50. [CrossRef]

3. Engebø, A.; Lædre, O.; Young, B.; Larssen, P.F.; Lohne, J.; Klakegg, O.J. Collaborative project delivery methods: A scoping review. J. Civil Eng. Manag. 2020, 26, 278-303. [CrossRef]

4. Lloyd-Walker, B.; Walker, D. Collaborative Project Procurement Arrangements; Project Management Institute: Newtown Square, PA, USA, 2015.

5. Fischer, M.; Khanzode, A.; Ashcraft, H.W.; Reed, D. Integrating Project Delivery; John Wiley \& Sons: Hoboken, NJ, USA, 2017.

6. Oakland, J.S.; Marosszeky, M. Total Construction Management: Lean Quality in Construction Project Delivery; Routledge: Abingdon, UK, 2017.

7. Laan, A.; Voordijk, H.; Dewulf, G. Reducing opportunistic behaviour through a project alliance. Int. J. Manag. Proj. Bus. 2011, 4, 660-679. [CrossRef]

8. Ibrahim, M.W.; Hanna, A.; Kievet, D. Quantitative comparison of project performance between project delivery systems. J. Manag. Eng. 2020, 36, 04020082. [CrossRef]

9. Hällgren, M.; Lindahl, M.; Karrbom Gustavsson, T.; Gohary, H. Boundary action in construction projects: New collaborative project practices. Int. J. Manag. Proj. Bus. 2012, 5, 364-376. [CrossRef]

10. Abdullah, A.H.; Yaman, S.K.; Mohammad, H.; Hassan, P.F. Construction manager's technical competencies in Malaysian construction projects. Eng. Constr. Archit. Manag. 2018, 25, 153-177. [CrossRef]

11. Alvarenga, J.C.; Branco, R.R.; Guedes, A.L.A.; Soares, C.A.P.; e Silva, W.D.S. The project manager core competencies to project success. Int. J. Manag. Proj. Bus. 2019. [CrossRef]

12. Mutijwaa, P.; Rwelamila, D. Project Management Competence in Public Sector Infrastructure Organisation. Constr. Manag. Econ. 2007, 25, 55-66. [CrossRef]

13. Panas, A.; Pantouvakis, J.P.; Lambropoulos, S. A simulation environment for construction project manager competence development in construction management. Procedia-Soc. Behav. Sci. 2014, 119, 739-747. [CrossRef]

14. Müller, R.; Turner, J.R. Matching the project manager's leadership style to project type. Int. J. Proj. Manag. 2007, 25, 21-32. [CrossRef]

15. Spencer, M.L.; Spencer, M.S. Competence at Work: Models for Superior Performance; John Wily \& Son. Inc.: New York, NY, USA, 1993.

16. Zhang, F.; Zuo, J.; Zillante, G. Identification and evaluation of the key social competencies for Chinese construction project managers. Int. J. Proj. Manag. 2013, 31, 748-759. [CrossRef]

17. Toney, F. The Superior Project Manager: Global Competency Standards and Best Practices; CRC Press: Boca Raton, FL, USA, 2001.

18. MacInnis, P. Skill test question. Comput. Can. 2003, 29, 10.

19. Ahadzie, D.K.; Proverbs, D.G.; Olomolaiye, P. Towards developing competency-based measures for construction project managers: Should contextual behaviours be distinguished from task behaviours? Int. J. Proj. Manag. 2008, 26, 631-645. [CrossRef]

20. Ahadzie, D.K.; Proverbs, D.G.; Olomolaiye, P.O.; Ankrah, N.A. Competencies required by project managers for housing construction in Ghana: Implications for CPD agenda. Eng. Constr. Archit. Manag. 2009, 16, 353-375. [CrossRef]

21. Chen, P.; Partington, D.; Wang, J.N. Conceptual determinants of construction project management competence: A Chinese perspective. Int. J. Proj. Manag. 2008, 26, 655-664. [CrossRef]

22. Dogbegah, R.; Owusu-Manu, D.; Omoteso, K. A principal component analysis of project management competencies for the Ghanaian construction industry. Australas. J. Constr. Econ. Build. 2011, 11, 26. [CrossRef]

23. Shah, M.N.; Prakash, A. Developing generic competencies for infrastructure managers in India. Int. J. Manag. Proj. Bus. 2018, 11, 366-381. [CrossRef]

24. Abraham, S.E.; Karns, L.A.; Shaw, K.; Mena, M.A. Managerial competencies and the managerial performance appraisal process. J. Manag. Dev. 2001, 20, 842-852. [CrossRef]

25. McClelland, D.C. Testing for competence rather than for "intelligence". Am. Psychol. 1973, 28, 1. [CrossRef]

26. McClelland, D.C. Human Motivation; Scott, Foresman: Glenview, IL, USA, 1985.

27. Boyatzis, R.E. The Competent Manager: A Model for Effective Performance; John Wiley\& Sons: New York, NY, USA, 1982.

28. Boyatzis, R.E. Competencies in the twenty-first century. J. Manag. Dev. 2008, 27, 5-12. [CrossRef]

29. Boyatzis, R.E. Competencies as a behavioral approach to emotional intelligence. J. Manag. Dev. 2009, 28, 749-770. [CrossRef]

30. Zwell, M. Creating a Culture of Competence; Wiley: Hoboken, NJ, USA, 2000.

31. Moradi, S.; Kähkönen, K.; Aaltonen, K. Comparison of research and industry views on project managers' competencies. Int. J. Manag. Proj. Bus. 2019, 13, 543-572. [CrossRef]

32. Gaddis, P.O. The project manager. Harv. Bus. Rev. 1959, 37, 89-97.

33. Lawrence, P.R.; Lorsch, J.W. New Management Job: The Integrator. Harv. Bus. Rev. 1967. Available online: https://hbr.org/1967 $/ 11 /$ new-management-job-the-integrator (accessed on 22 December 2020).

34. Powers, E.A. Enhancing managerial competence: The American management association competency programme. J. Manag. Dev. 1987, 6, 7-18. [CrossRef] 
35. Crawford, L. Profiling the competent project manager. In Proceedings of PMI Research Conference ( $p p$. 3-15); Project Management Institute: Newtown Square, PA, USA, 2000.

36. Edum-Fotwe, F.T.; McCaffer, R. Developing project management competency: Perspectives from the construction industry. Int. J. Proj. Manag. 2000, 18, 111-124. [CrossRef]

37. Shenhar, A.J. One size does not fit all projects: Exploring classical contingency domains. Manag. Sci. 2001, 47, 394-414. [CrossRef]

38. Patanakul, P.; Milosevic, D. A competency model for effectiveness in managing multiple projects. J. High Technol. Manag. Res. 2008, 18, 118-131. [CrossRef]

39. Stevenson, D.H.; Starkweather, J.A. PM critical competency index: IT execs prefer soft skills. Int. J. Proj. Manag. 2010, 28 , 663-671. [CrossRef]

40. Klendauer, R.; Berkovich, M.; Gelvin, R.; Leimeister, J.M.; Krcmar, H. Towards a competency model for requirements analysts. Inf. Syst. J. 2012, 22, 475-503. [CrossRef]

41. Kostalova, J.; Bednarikova, M.; Patak, M. The Required Competencies of Project Managers in Metallurgical Companies in the Czech Republic. Metalurgija 2018, 57, 131-134. Available online: https:/ /hrcak.srce.hr/189383 (accessed on 22 December 2020).

42. El-Sabaa, S. The skills and career path of an effective project manager. Int. J. Proj. Manag. 2001, 19, 1-7. [CrossRef]

43. Kasvi, J.J.; Vartiainen, M.; Hailikari, M. Managing knowledge and knowledge competences in projects and project organisations. Int. J. Proj. Manag. 2003, 21, 571-582. [CrossRef]

44. Ruuska, I.; Vartiainen, I. Critical project competences-A case study. J. Workplace Learn 2003, 15, 307-312. [CrossRef]

45. Dainty, A.R.; Cheng, M.I.; Moore, D.R. A competency-based performance model for construction project managers. Constr. Manag. Econ. 2004, 22, 877-886. [CrossRef]

46. Cheng, M.I.; Dainty, A.R.; Moore, D.R. What makes a good project manager? Hum. Resour. Manag. J. 2005, 15, 25-37. [CrossRef]

47. Gillard, S.; Price, J. The competencies of effective project managers: A conceptual analysis. Int. J. Manag. 2005, $22,48$.

48. Brill, J.M.; Bishop, M.J.; Walker, A.E. The competencies and characteristics required of an effective project manager: A web-based Delphi study. Educ. Technol. Res. Dev. 2006, 54, 115-140. [CrossRef]

49. Suikki, R.; Tromstedt, R.; Haapasalo, H. Project management competence development framework in turbulent business environment. Technovation 2006, 26, 723-738. [CrossRef]

50. Fisher, E. What practitioners consider to be the skills and behaviours of an effective people project manager. Int. J. Proj. Manag. 2011, 29, 994-1002. [CrossRef]

51. Lee, T.S.; Kim, D.H.; Lee, D.W. A competency model for project construction team and project control team. KSCE J. Civil Eng. 2011, 15, 781-792. [CrossRef]

52. Walker, D.; Lloyd-Walker, B. Knowledge, skills and attributes of project alliances managers in Australasia. In Proceedings of the ARCOM Twenty Seventh Annual Conference held at the University of Western England, Bristol, UK, 5-7 September 2011; University of Reading: Reading, UK, 2011.

53. Hwang, B.G.; Ng, W.J. Project management knowledge and skills for green construction: Overcoming challenges. Int. J. Proj. Manag. 2013, 31, 272-284. [CrossRef]

54. laili Jabar, I.; Ismail, F.; Aziz, N.M.; Janipha, N.A.I. Construction manager's competency in managing the construction process of IBS projects. Procedia-Soc. Behav. Sci. 2013, 105, 85-93. [CrossRef]

55. Liyana Othman, N.; Jaafar, M. Personal competency of selected women construction project managers in Malaysia. J. Eng. Des. Technol. 2013, 11, 276-287. [CrossRef]

56. Trivellas, P.; Drimoussis, C. Investigating leadership styles, behavioural and managerial competency profiles of successful project managers in Greece. Procedia-Soc. Behav. Sci. 2013, 73, 692-700. [CrossRef]

57. Ahadzie, D.K.; Proverbs, D.G.; Sarkodie-Poku, I. Competencies required of project managers at the design phase of mass house building projects. Int. J. Proj. Manag. 2014, 32, 958-969. [CrossRef]

58. Crayon, C.; Patton, S.A.G.T.; Steigerwald, A. Competencies for Today's Australian Project Manager. J. Econ. Dev. Manag. IT Financ. Mark. 2017, 9, 24.

59. De los Ríos-Carmenado, I.; Rahoveanu, A.T.; Gallegos, A.A. Project management competencies for regional development in Romania: Analysis from "Working with People" model. Procedia Econ. Financ. 2014, 8, 614-621. [CrossRef]

60. Dziekoński, K. Project managers' competencies model for construction industry in Poland. Procedia Eng. 2017, 182, 174-181. [CrossRef]

61. Moradi, S.; Arbabi, H.; Goldust Jouybari, Y. Matching Iranian project manager's competencies to project type (Case study: IT and construction industry projects). In Proceedings of the International Congress on Science and Engineering, Hamburg, Germany, 14-15 March 2018.

62. Omar, M.N.; Fayek, A.R. Modeling and evaluating construction project competencies and their relationship to project performance. Autom. Constr. 2016, 69, 115-130. [CrossRef]

63. Takey, S.M.; de Carvalho, M.M. Competency mapping in project management: An action research study in an engineering company. Int. J. Proj. Manag. 2015, 33, 784-796. [CrossRef]

64. Tabassi, A.A.; Roufechaei, K.M.; Ramli, M.; Bakar, A.H.A.; Ismail, R.; Pakir, A.H.K. Leadership competences of sustainable construction project managers. J. Clean. Prod. 2016, 124, 339-349. [CrossRef]

65. Liikamaa, K. Developing a project manager's competencies: A collective view of the most important competencies. Procedia Manuf. 2015, 3, 681-687. [CrossRef] 
66. International Project Management Association. Individual Competence Baseline for Project, Programme E Portfolio Management; IPMA: Zurich, Switzerland, 2015.

67. Project Management Institute. Project Manager Competency Framework (PMCD.3); Project Management Institute: Newtown Square, PA, USA, 2017.

68. Association for Project Management. APM Body of Knowledge; Association for Project Management: Buckinghamshire, UK, 2012.

69. Project Management Institute. A Guide to the Project Management Body of Knowledge (PMBOK®Guide)—Sixth Edition; Project Management Institute: Newtown Square, PA, USA, 2017.

70. Nurminen, K. Deltoid-The Competencies of Nuclear Power Plant Operators. Master's Thesis, Tampere University of Technology, Pori, Finland, 2003.

71. Saunders, M.N.K.; Lewis, P.; Thornhill, A. Research Methods for Business Students, 8th ed.; Pearson Education Limited: Harlow, UK, 2019.

72. Chang, Y.; Eklund, T.; Kantola, J.I.; Vanharanta, H. International creative tension study of university students in South Korea and Finland. Hum. Factors Ergon. Manuf. Serv. Ind. 2009, 19, 528-543. [CrossRef]

73. Senge, P.M. The Fifth Discipline: The Art E Practice of Learning Organization; Currency Doubleday: New York, NY, USA, 1990.

74. Liikamaa, K. Tacit Knowledge and Project Managers' Competences. Ph.D. Thesis, Tampere University of Technology, Pori, Finland, 2006.

75. Goleman, D. Working with Emotional Intelligence; Bantam Books: New York, NY, USA, 1998.

76. Bikfalvi, A.; Pagès, J.L.; Gou, P.M.; Kantola, J.; Vanharanta, H. Testing a new tool for competence self-evaluation and development: Students as project managers. In Proceedings of the IADIS International Conference Cognition and Exploratory Learning in Digital Age, Barcelona, Spain, 8-10 December 2006; pp. 194-200, ISBN 972-8924-22-4.

77. Paajanen, P.; Porkka, P.; Paukku, H.; Vanharanta, H. Development of personal and organizational competencies in a technology company. Hum. Factors Ergon. Manuf. Serv. Ind. 2009, 19, 568-581. [CrossRef]

78. Hosseini, A.; Wondimu, P.A.; Bellini, A.; Haugseth, N.; Andersen, B.; Lædre, O. Project partnering in Norwegian construction industry. Energy Procedia 2016, 96, 241-252. [CrossRef]

79. Stone, R. Human Resource Management, 3rd ed.; John Wiley \& Sons: Brisbane, Australia, 1998; 854p.

80. Dessler, G. A Framework for Human Resource Management, 2nd ed.; Prentice Hall: Upper Saddle River, NJ, USA, 2001; 320p.

81. Torrington, D.; Hall, L. Personnel Management_A New Personnel Approach, 2nd ed.; Prentice Hall: London, UK, 1991; 661p.

82. Geraldi, J.; Maylor, H.; Williams, T. Now, let's make it really complex (complicated). Int. J. Oper. Prod. Manag. 2011. [CrossRef] 